\title{
Evidence for rapid recovery of shark populations within a coral reef marine protected area
}

\author{
Conrad W. Speed ${ }^{\mathrm{a}, \mathrm{b}, *}$, Mike Cappo ${ }^{\mathrm{a}}$, and Mark G. Meekan ${ }^{\mathrm{a}, \mathrm{b}}$ \\ ${ }^{a}$ Australian Institute of Marine Science, Indian Ocean Marine Research Centre, UWA (MO96), 35 Stirling Hwy, \\ Crawley Western Australia 6009, Australia, \\ ${ }^{\mathrm{b}}$ Global FinPrint Project, AIMS, UWA (MO96), 35 Stirling Hwy, Crawley Western Australia 6009, Australia \\ * Australian Institute of Marine Science, Indian Ocean Marine Research Centre, The University of Western \\ Australia (MO96), 35 Stirling Hwy, Crawley Western Australia 6009, Australia. \\ E-mail address: c.speed@aims.gov.au
}

\begin{abstract}
There is limited evidence on the rate at which the shark populations of coral reefs can rebound from over-exploitation, the baselines that might signify when recovery has occurred and the role of no-take Marine Protected Areas (MPA) in aiding this process. We surveyed shark assemblages at Ashmore Reef in Western Australia using baited remote underwater video Stations in 2004 prior to enforcement of MPA status and then again in 2016 after eight years of strict enforcement. We found an increase in the relative mean abundance of Carcharhinus amblyrhynchos from $0.16 \pm 0.06$ individuals $/ \mathrm{hr}^{-1}$ in 2004 to $0.74 \pm 0.11$ individuals $/ \mathrm{hr}^{-1}$ in 2016 , a change that was also accompanied by a shift in the assemblage of sharks to greater proportions of apex species (from $7.1 \%$ to $11.9 \%$ ) and reef sharks (from $28.6 \%$ to $57.6 \%$ ), and a decrease in the proportional abundance of lower trophic level species (from $64.3 \%$ to $30.5 \%$ ). Abundances and trophic assemblage of sharks at Ashmore Reef in 2004 resembled those of the Scott Reefs, where targeted fishing for sharks still occurs, whereas in 2016, abundances and trophic structures had recovered to resemble those of the Rowley Shoals, a reef system that has been a strictly enforced MPA for over 25 years. The shift in abundance and community structure coincident with strict enforcement of the MPA at Ashmore Reef has occurred at a rate greater than predicted by demographic models, implying the action of compensatory processes in recovery. Our study shows that shark communities can recover rapidly after exploitation in a well-managed no-take MPA.
\end{abstract}

\section{Keywords}

Carcharhinus amblyrhynchos, Global Finprint Program, artisanal fishing, BRUVS, Ashmore Reef, illegal fishing. 


\section{Introduction}

The k-selected life history traits of slow growth, long life spans, late sexual maturity, long gestation periods and reduced fecundity of sharks (Cortes 2000) imply inherently slow rates of recovery $\left(4-5 \% \mathrm{yr}^{-1}\right)$ from population declines. Coupled with high rates of exploitation (6-8\% $\left.\mathrm{yr}^{-1}\right)$ by fishing in response to market demand (Clarke et al. 2006; Worm et al. 2013), this has resulted in many populations of sharks being depleted at a rate that exceeds their natural recovery potential (Worm et al. 2013). In tropical ecosystems, fishing has caused declines in common species of sharks in many localities worldwide. For example, there have been losses of reef sharks of $7-17 \%$ per annum on the Great Barrier Reef (Robbins et al. 2006), over a 90\% decline on reefs in the Chagos Archipelago since the 70s (Graham et al. 2010), and modelled estimates of declines in abundance to 3-10\% of baseline values on reefs in the central-western Pacific (Nadon et al. 2012).

Declining populations of sharks in the tropics are of concern because of increasing evidence of their important trophic role (Heithaus et al. 2010; Heupel et al. 2014; Roff et al. 2016; Ruppert et al. 2013). The presence of sharks has been shown to affect the diet, condition and morphology of their prey (Barley et al. 2017a, b) and food chain structure (Barley et al. 2017a). There is also evidence that the absence of predators may affect the ability of reefs to recover from disturbances that remove coral cover (e.g. cyclones and bleaching) (Ruppert et al. 2013) and promote outbreaks of corallivores (e.g. crown-of-thorns starfish Acanthaster plancii (Dulvy et al. 2004; Ruppert et al. 2013), which is a major issue in a world facing climate change (Hughes et al. 2003). However, there is still some uncertainty around the exact functional role reef sharks play in structuring reef communities, which is due to the complex nature of ecosystem dynamics and unknown exploitation histories (Roff et al. 2016). For many coastal and island nations in the tropics, sharks are also a valuable tourism resource that support industries that provide significant benefits to regional economies (Brunnschweiler 2010; Gallagher and Hammerschlag 2011; Huveneers et al. 2017; Vianna et al. 2012).

An understanding of the rate at which populations of reef sharks might recover, and the management strategies that might enhance this goal are hampered by a lack of field observations of this process. Estimates of recovery rates are largely based on modelling of demographic rates of growth, reproduction and survivorship (Cortes 2002; Hisano et al. 2011; Smith et al. 1998) that often do not include estimates of density-dependant factors such as competition, predation, cannibalism, immigration and emigration. Moreover, once circumstances have allowed recovery to begin, the endpoint of the process is uncertain, since there are few baselines that might indicate what a "pristine" (unfished) shark community might look like (Nadon et al. 2012). This uncertainty is largely due to the ubiquitous nature of fishing in coral reef ecosystems worldwide (Newton et al. 2007). These issues are pertinent to the establishment of management strategies such as marine protected areas (MPAs) (Bond et al. 2012; White et al. 2017) and shark sanctuaries (Ward-Paige et al. 2012) that have been promoted as a means of ensuring the conservation and recovery of shark populations. They add to other unanswered questions about this approach to management and its efficacy (Davidson 2012), such as the optimal size and placement of MPAs, whether they are useful for all components of a shark fauna including wide-ranging apex predators (Ward-Paige et al. 2012) and mesopredators (White et al. 2017), and the level of enforcement that is required to have desired effects for shark populations (Ward-Paige 2017). It is generally agreed that strict enforcement is paramount to the success of an MPA (Chapman et al. 2013; Dulvy 2006; Edgar et al. 2014; Gill et al. 2017), although even well-managed parks such as the Great 
Barrier Reef Marine Park have seen declines in common species of reef sharks due to illegal fishing in no-take zones (Robbins et al. 2006).

Coral reef systems in the north-west of Western Australia (WA) offer a unique opportunity to examine the recovery of reef shark populations from fishing and the role of MPAs in this process, within the context of a large-scale (hundreds of km, multiple reefs) natural experiment. Three atoll-like reefs systems, Ashmore Reef, the Scott Reefs, and the Rowley Shoals occur at the edge of the continental shelf in this region. Prior to 1998, Ashmore Reef was subjected to both targeted shark fishing and subsistence fishing (both legal and illegal) by Indonesian fishermen. A no-take MPA was established at this time and enforced through occasional monitoring from 2004 and then by the continuous presence of a government vessel from 2008. The Scott Reefs to the south of Ashmore Reef have been subjected to targeted fishing for sharks by Indonesian fishermen for centuries, a phenomenon that is still ongoing today (Meekan et al. 2006; Vince 2007). In contrast, the Rowley Shoals that lie to the south west of the Scott Reefs have been an MPA for over 25 years and are subject to very low or negligible levels of fishing pressure (Conservation 2007). Surveys at Ashmore Reef collected in 2004 and then again 12 years later in 2016 following these changing conditions of enforcement of MPA regulations provided our study with an ideal platform to monitor the rate and outcome of the recovery of shark populations. By comparing results for Ashmore Reef with those of surveys of Scott Reefs and the Rowley Shoals, we were able to identify changes in the structure and abundance of shark communities that might indicate a return to pre-fishing levels and to examine the effectiveness of MPAs as a conservation tool for the recovery of shark populations. We focus our study on the grey reef shark, Carcharhinus amblyrhynchos, as an indicator species of recovery given that it is one of the most common species of reef shark in the Indo-Pacific and targeted for its fins by both legal and illegal fishing (Marshall 2011). We compare predicted rates of recovery for this species with direct observations in order to identify the potential role and importance of density-dependant factors in the recovery process.

\section{Material and methods}

\subsection{Study site and background}

\subsubsection{Ashmore Reef}

Ashmore Reef $\left(12^{\circ} 14.929^{\prime} \mathrm{S}, 123^{\circ} 3.319 \mathrm{E}\right)$ is a large, lagoonal platform reef $(26 \mathrm{~km}$ long and $14 \mathrm{~km}$ wide) with three low vegetated islands on the North-West Shelf of Australia, rising from the edge of the continental slope (Wilson 2013) (Figure 1). The reef is situated $c a$. $350 \mathrm{~km}$ from the mainland of north-west Australia; its closest reef system is the island of Roti in Indonesia, which is situated ca. $145 \mathrm{~km}$ to the north (Berry 1993).

Ashmore Reef National Nature Reserve was proclaimed in $1983\left(583 \mathrm{~km}^{2}\right)$, although traditional fishing by Indonesian artisanal fishers was permitted at Ashmore Reef and Scott Reefs by way of a memorandum of understanding (MOU) with the Australian Government until 1988 (Australia 2002). After this time, a no-take MPA that banned all fishing was declared at Ashmore Reef, although West Island lagoon, a small area in the centre of the reef, was exempted from this restriction to allow subsistence fishing. Despite protection status, illegal fishing for sharks and reef fishes continued up into the 2000s (Field et al. 2009), as

any enforcement of the MPA was difficult due to the remote location of Ashmore and the proximity of the reef to Indonesia. Between 2000 and 2006, Australian Border Force vessels 
made sporadic patrols, although from 2008 a vessel was deployed at Ashmore Reef on a nearpermanent basis (300 continuous days per year) (DIBP 2017). Ashmore Reef was thus considered to be a 'fished reef' pre-2008 and a fully protected reef post- 2008 .

\subsubsection{Scott Reefs}

The Scott Reefs consist of three large atolls on the edge of the continental shelf: Seringapatam Reef ( 8 x 9.4 km); Scott Reef North (16.3 x 14.4 km); and Scott Reef South $(27.4 \times 17 \mathrm{~km})$, which are located $c a .260 \mathrm{~km}$ from the mainland of north-western Australia $\left(14^{\circ} 0^{\prime} \mathrm{S}, 121^{\circ} 45^{\prime} \mathrm{E}\right), 400 \mathrm{~km}$ north-east of the Rowley Shoals and $200 \mathrm{~km}$ south of Ashmore Reef (Berry 1986) (Figure 1). The Scott Reefs have been fished by Indonesian artisanal fishers since at least the 1800s (Russell and Vail 1988) who have targeted sharks for fins and collected reef fishes for subsistence. The Scott Reefs and Ashmore Reef lie within the "MOU Box" (Figure 1) where Indonesian fishermen are still permitted to fish using traditional techniques by agreement with the Australian Government, although not within Ashmore Reef MPA (Meekan et al. 2006).

\subsubsection{Rowley Shoals}

This system is composed of three large reefs: Imperieuse $(17.8 \times 9.5 \mathrm{~km})$; Clerke $(15.8 \times 7.6 \mathrm{~km})$, and Mermaid $(14.5 \times 7.6 \mathrm{~km})$ (Berry 1986), which are to the south of the MOU box and share the same position at the edge of the continental shelf as the Scott and Ashmore reefs. Unlike the Scott Reefs, Rowley Shoals are a no-take MPA and marine reserve (est. 1990) that are subject to only very small amounts of charter fishing that mostly targets tunas and billfishes (Conservation 2007; Figure 1). The Rowley Shoals are therefore considered to be a baseline of "pristine" (unfished) abundances of sharks against which changes in numbers and trophic structures of shark communities at Ashmore Reef and the Scott Reefs can be compared.

\subsection{Data collection}

Data were collected using Baited Remote Underwater Video Stations (BRUVS) in shallow water $(<60 \mathrm{~m})$ around Ashmore Reef in October 2004 and January 2016, and the Scott Reefs and the Rowley Shoals in September 2016. The 2004 survey around Ashmore Reef was part of a larger survey of shark stocks in the MOU Box (Meekan et al. 2006). The 2016 surveys were conducted as part of the Global FinPrint Project https://globalfinprint.org/. The BRUVS consisted of a galvanized or aluminium frame enclosing a camera housing made from PVC pipe with flat acrylic ports. Sony TRV18E MiniDV Handicams with wide-angle lenses $(0.6 \mathrm{x})$ were used in housings in 2004 and GoPro Hero4 Silver Edition were used in 2016. Cameras were set to a medium field of view (FOV) in 2016 to ensure compatibility with cameras used for the 2004 surveys. The FOV for cameras in 2004 at $1 \mathrm{~m}$ was $0.96 \mathrm{~m}$ (horizontal) and $0.71 \mathrm{~m}$ (vertical), while cameras in 2016 had an FOV at $1 \mathrm{~m}$ of $1.26 \mathrm{~m}$ (horizontal) and $0.71 \mathrm{~m}$ (vertical). It is not possible to standardise the perimeter of the field of view with single cameras, although it can be set with stereo-video systems (see Harvey et al. 2002). The perimeter of the field of view depends on water clarity and illumination, as well as the size of the sharks relative to the resolution of the cameras. However, it is possible to adjust the FOV during video playback, which allowed us to reanalyse a subsample of our 
videos to check for consistency of sampling with differing FOV between sampling periods (Figure A.1).

A bait bag containing $1 \mathrm{~kg}$ of crushed pilchards (Sardinops spp.) was suspended at the end of a $1.5 \mathrm{~m}$ pole in front of the camera. BRUVS were deployed to provide $60-90$ minutes of video recorded at the seabed. Successive deployments within a set were spaced between 400 to $1000 \mathrm{~m}$ apart in shallow depths $(4-58 \mathrm{~m})$ around the reef during daylight hours. BRUVS were spaced $>400 \mathrm{~m}$ apart to minimise the likelihood of overlapping bait plumes. Deployments were more evenly distributed in 2004 along shallow reef contours, whereas deployments in 2016 were randomly placed along reef contours and associated shallow habitats (Figure 1). Deployments around the Scott Reefs and Rowley Shoals in 2016 were focussed on the leeward side of the reef (eastern side of atoll), as this is provided representative shallow reef slope habitat and safe working conditions (Table 1 and Figure A.2).

\subsection{Habitat classification \& video interrogation}

Habitats were classified from a still reference image taken from the beginning of each BRUVS deployment video. Visual estimates of coral cover $(0-100 \%$ rounded to the nearest $5 \%$ ), complexity (Low, Medium, and High), and habitat type (Sand, Reef, Other) were estimated by eye, similar to other studies (Espinoza et al. 2014; Malcolm et al. 2011; Tickler et al. 2017). All visible habitat was included in the classification process. Such visual estimates have been shown to be similar to those obtained by dedicated techniques including line-intercept transects (Wilson et al. 2007).

GoPro video footage from BRUVS deployed in 2016 was stitched and converted to avi format using Xilisoft Video Converter prior to being analysed with EventMeasure (www.seagis.com). The maximum number of sharks seen at any one time on screen throughout each video (MaxN) was used as a measure of relative abundance (Ellis and DeMartini 1995; Meekan et al. 2006; Willis and Babcock 2000).

\subsection{Data analyses}

Relative abundances of sharks (MaxN) were standardised to the soak time, to produce a rate of shark sightings per hour of soak time to allow comparisons with earlier studies at both regional and global scales. Videos with aggregations of sharks (MaxN $>15-$ Scott Reef $=1$ video, and Rowley Shoals $=1$ video) were removed from mean abundance per hour estimates, as these disproportionally upwardly biased estimates for these locations.

In order to make comparisons among sampling years and different reef systems, the proportion of the shark assemblage that each species represented was calculated. Sharks were classified into broad trophic groups (based on Hammerschlag Under Review) as: a) 'Higher Trophic Position' (Apex predators such as: Galeocerdo cuvier, Negaprion acutidens, Sphyrna lewini, and Hemipristis elongata), b) Reef Sharks (Carcharhinus albimarginatus, $C$. amblyrhynchos, and C. melanopterus), and C) Lower Trophic Position (Nebrius ferrugineus, Stegostoma fasciatum, Triaenodon obesus, Hemitriakis falcata, and Atelomycterus fasciatus). A Pearson's chi-squared goodness of fit test was used to determine whether community composition differed among reefs and through time at Ashmore Reef (Agresti 1996). This 
technique was applied to the total MaxN of each trophic position grouping per reef and for both of the years (2004 and 2016) when Ashmore was sampled.

Rates of recovery for C. amblyrhynchos between our surveys of 2004 and 2016 were calculated based on intrinsic rates of rebound for this species given by Smith et al. (1998), as well as estimates of natural population growth in the absence of fishing from multiple models collated by Hisano et al. (2011). These rates were used to calculate predicted increases in the mean number $\mathrm{hr}^{-1}$ of C. amblyrhynchos recorded by BRUVS between 2004 and 2016 given the absence of any mortality through fishing. The first model provided by Smith et al. (1998) gave a productivity estimate $\left(\mathrm{r}_{2 \mathrm{~m}}\right)$ of $5.4 \%$ increase per year, which assumed that increases occur through increased survivorship of adults, while the second model estimated an $\mathrm{r}_{2 \mathrm{~m}}$ of $7.8 \%$ increase per year, which accounted for increased fecundity in an expanding population (Smith et al. 1998). The third group of models were Leslie matrix population models, which provided a number of estimates of survival based on varying natural mortality estimates (Hisano et al. 2011). These estimates were then combined to produce a consensus estimate of natural growth, which was a bias-corrected median of growth in the absence of fishing mortality of $2 \%$ per year (Hisano et al. 2011).

Generalised Linear Models (GLMs) with Poisson and Negative Binomial distributions were used to test for an effect of habitat variables and time between the two sampling periods (2004 and 2016) on abundance of C. amblyrhynchos. Given there was a high percentage of zeros present in the dataset $(65 \%)$, a Zero-Inflated model with a Poisson distribution was also fitted. Model residuals were plotted against fitted values as were model residuals plotted against covariates to determine whether model assumptions were met (Zuur et al. 2007). Models included the explanatory variables depth, coral cover, habitat type, habitat complexity and year. To address differences in deployment times of BRUVS, 'soak time' was used as an offset within the model structure (e.g. Espinoza et al. 2014). A data exploration phase was used to determine whether there was any collinearity among variables. Coral and depth were determined to be correlated (Pearson Correlation $=0.5$ ) and therefore not included within the same models. Models were ranked using Akaike's Information Criterion corrected for small sample sizes $\left(\mathrm{AIC}_{c}\right)$ and $\mathrm{AIC}_{c}$ weights $\left({ }_{w} \mathrm{AIC}_{c}\right)$ (Burnham and Anderson 2002).

Overdispersion was assessed using Pearson residuals, where a score of close to 1 is indicative of a lack of over-dispersion (Zuur et al. 2009). All analyses used the Program R with packages MASS to fit Negative Binomial models (Venables and Ripley 2002), pscl to fit Zero-Inflated models (Jackman et al. 2007), MuMIn to rank models (Bartoń 2013), Visreg to assess partial residuals (Breheny and Burchett 2013), and hier.part to assess variance partitioning of models (Walsh et al. 2003).

\section{Results}

\subsection{Ashmore Reef}

The mean number of $C$. amblyrhynchos $\mathrm{hr}^{-1}$ sighted on BRUVS surveys differed significantly between 2004 and 2016. In 2004, MaxN averaged 0.16 ( \pm 0.06 SE), whereas in 2016 abundances were 4.6 times greater with MaxN averaging $0.74( \pm 0.11 \mathrm{SE})$ (Figure 2A). The greatest number of sharks seen on one deployment in 2004 was a MaxN of two individuals, compared to a MaxN of four individuals in 2016. Shark numbers were highest in 2016 around the western edge of the reef slope, a pattern that was not observed in 2004 (Figure 3). Given the average abundances we observed in 2004, intrinsic rate of increase models for C. amblyrhynchos (Smith et al. 1998) and natural population growth models 
(Hisano et al. 2011) suggested that a time interval of 20 to 80 years would be required to attain the mean abundances we observed in 2016, depending on the growth model adopted (Figure 2B). This was a far greater time period than the 12-year span between our BRUVS surveys.

The effect of sampling year and environmental variables on C. amblyrhynchos abundance was tested using Poisson distributed Generalised Linear Models (GLMs). The Poisson GLM that included year, habitat, and complexity provided the top-ranked fit $\left(w \mathrm{AIC}_{\mathrm{c}}\right.$ $=0.60)$ and explained the highest amount of deviation (D.E. $=33.10 \%)($ Table 2$)$. This model was preferred over the Negative Binomial and Zero-Inflated Models as they were all within 2 AIC of each other and for this reason, the Poisson model was selected as the most parsimonious. There was little evidence of overdispersion of the top ranked model (overdispersion value 0.97 ). Variance partitioning attributed $50 \%$ of the variance in the data to the factor 'year' and 26\% to 'habitat' (Figure A.3). Environmental variables attributed to higher shark abundance were non-sandy habitats (i.e. reef or other habitat with vertical relief) (Figure 4B) and low to medium habitat complexity (Figure 4C).

\subsection{Scott Reefs and Rowley Shoals}

In 2016 the mean number of $C$. amblyrhynchos $\mathrm{hr}^{-1}$ differed between the Scott Reefs and the Rowley Shoals, with the former having lower numbers $(0.15 \pm 0.04 \mathrm{SE})$ of sharks compared to the latter $(0.65 \pm 0.14 \mathrm{SE}$; Figure A.4). When videos that featured aggregations of $C$. amblyrhynchos at both sites were included in the data, the greatest number of sharks seen on one deployment at Scott Reefs was a MaxN of 21 individuals (recorded at North Scott Reef), compared to a MaxN of 18 individuals at Rowley Shoals (recorded at Imperieuse Reef).

\subsection{Comparison of trophic structure at Ashmore Reef, Rowley Shoals and Scott Reefs}

The composition of the shark assemblage at Ashmore Reef in 2004 when the reef was open to fishing was similar to that of the Scott Reefs (still open to fishing) sampled in 2016 (Figure 5). Both reefs had shark faunas that were dominated by species that occupied lower trophic positions in the food chain (64.3\% of the total fauna at Ashmore in 2004, 61.9\% of the fauna at Scott Reefs in 2016), rather than reef sharks (28.6\% of fauna at Ashmore, 38.1\% of fauna at Scott Reefs) (Table 3 and Figure 5). However, despite similarities in proportional community structure, a significant difference was found between both reef communities using combined MaxN data $\left(\mathrm{X}^{2}=7.43, \mathrm{df}=2, \mathrm{p}=0.024\right)$. The trophic assemblage of sharks shifted significantly in the 12 years between our surveys at Ashmore $\left(X^{2}=12.21, \mathrm{df}=2, \mathrm{p}=\right.$ $0.002)$. We recorded a low proportion of reef sharks $(28.6 \%)$ in 2004 , which increased to a much higher proportion (57.6\%) in 2016 (Figure 5). There was also a small increase in higher trophic position sharks from $7.1 \%$ in 2004 to $11.9 \%$ in 2016 . Conversely, sharks in lower trophic positions declined in proportional abundance from $64.3 \%$ of the assemblage in 2004 to $30.5 \%$ in 2016 . After 12 years of protection, the shark assemblage at Ashmore Reef was comparable to the Rowley Shoals $\left(\mathrm{X}^{2}=5.5647, \mathrm{df}=2, \mathrm{p}=0.061\right)$, which has been subjected to very little fishing pressure over the last 25 years. These changes in composition were mirrored by similar changes in abundance at Ashmore Reef. In 2004, mean numbers of $C$. amblyrhynchos $\left(0.16 \mathrm{hr}^{-1}\right)$ were very similar to those found in 2016 at the Scott Reefs $(0.15$ $\mathrm{hr}^{-1}$ ) (Figure A.4). Following protection, abundances of C. amblyrhynchos at Ashmore Reef 
in $2016\left(0.74 \mathrm{hr}^{-1}\right)$ are now equivalent to those recorded in 2016 at the Rowley Shoals $(0.65$ $\left.\mathrm{hr}^{-1}\right)$.

\section{Discussion}

Our study provides some of the first data on the rate of recovery of reef shark populations in a coral reef ecosystem. Examples of increasing (Espinoza et al. 2014) or even stable (Bradley et al. 2017) populations of reef sharks in these environments are very rare. Over the study period of 12 years we found that abundances of the most common species, $C$. amblyrhynchos, increased four-fold on Ashmore Reef. This increase was accompanied by changes in assemblage structure so that in 2016, both abundance and composition were comparable to those of shark communities on the Rowley Shoals, a reef system that has wellmanaged MPAs and has received negligible fishing pressure for almost three decades. For this reason, we argue that the shark populations of Ashmore Reef have effectively "recovered" from fishing pressures exerted by Indonesian fishermen prior to 2008 and now resemble baseline communities.

The rate of recovery of C. amblyrhynchos at Ashmore Reef was much faster than predicted by theory. Intrinsic rates of increase for the species (Smith et al. 1998) and population growth model estimates in the absence of fishing (Hisano et al. 2011), suggest that the abundances we observed should not have occurred until 2024, 2034, or even 2084, depending on the model applied to the data. The question as to why recovery has outstripped model predictions has a number of potential answers. One reason could be underestimation of the model parameters applied by Smith et al. (1998) (age at maturity 7 years, maximum age 18 years, fecundity 2.5 pups $\left.\mathrm{yr}^{-1}\right)$ to generate an increase of $5.4 \%$ year $^{-1}$. Recent research has revised these variables to larger ranges (age at maturity of 9 - 11 years; (Robbins 2006; Smart et al. 2016), maximum age of 12 - 19 years; (Radtke and Cailliet 1984; Robbins 2006; Smart et al. 2016), fecundity of $1-6$ pups year ${ }^{-1}$; (Robbins 2006; Stevens and McLoughlin 1991; Wetherbee et al. 1997) and C. amblyrhynchos in northern Australia has been found to have on average three pups year ${ }^{-1}$ (Stevens and McLoughlin 1991) and 3-4 pups year ${ }^{-1}$ on the Great Barrier Reef (Robbins 2006). The second model applied by Smith et al. (1998) increased fecundities by $25 \%$, a value more consistent with observed patterns, however population growth of $7.8 \%$ year $^{-1}$ still remained well below the values required to obtain the rate of recovery we observed. The most conservative of the three models of population growth was produced Hisano et al. (2011), which predicted only a $2 \%$ increase per year. This model used an estimate of longevity of between 19 and 25 years, whereas parameters for age at maturity and fecundity were obtained from Robbins et al. (2006). Under these conditions, $C$. amblyrhynchos populations would have required a recovery period seven times greater than the interval between our surveys to obtain the abundances we observed in 2016.

It may be that the recovery of sharks at Ashmore Reef was accelerated through densitydependent feedbacks in shark populations such as reduced competition, predation and cannibalism (Holden 1973). Removal of adults may have enhanced the growth rates of juveniles and thus the onset of maturity and also promoted greater fecundity in surviving adults (e.g. Carlson and Baremore 2003). Growth rates of juveniles could have increased both through the loss of conspecific competitors and the ability for smaller juveniles to occupy high-quality habitats where they might have been otherwise excluded or predated on by larger adults (e.g. Hussey et al. 2017). Additionally, targeted fishing for sharks also captures 
large mesopredatory teleosts, which are likely to act as competitors to reef sharks (Barley et al. 2017a, b; Roff et al. 2016; Ruppert et al. 2013).

Immigration of sharks from other localities adjacent to Ashmore Reef might also account for the rapid increase in abundances we recorded. Our study reef lies at the edge of the shelf with the nearest coral habitat (Cartier Reef) only $c a$. $50 \mathrm{~km}$ to the southeast, a distance easily negotiated by adult $C$. amblyrhynchos (Heupel et al. 2010; White et al. 2017). However, Cartier Reef is very small in size $(4.5 \mathrm{~km}$ by $2.3 \mathrm{~km})$ relative to Ashmore Reef. It is also an MPA that was subjected to targeted shark fishing by Indonesian fishermen prior to 2008. Cartier Reef was included in our surveys in 2004 (but not in 2016), at which time abundances and composition of the shark assemblage at both reefs were similar (Meekan et al. 2006). This suggests that Cartier Reef could have only provided a very limited source of immigrant sharks for recovering populations at Ashmore. Additionally, tracking studies at isolated reefs both in the same region (Rowley Shoals) and elsewhere in tropical Australia have shown that C. amblyrhynchos adults tend to be resident over protracted time frames (months -years) (Barnett et al. 2012; Espinoza et al. 2015; Field et al. 2011). This is confirmed by a recent genetic study that has shown that populations of $C$. amblyrhynchos on the Rowley Shoals and the Scott Reefs are likely to be largely self-recruiting and demographically independent (Momigliano et al. 2017). Although the proximity of other reefs and shoals to the east of Ashmore Reef may still increase the likelihood of immigration, this might have been counteracted by the prevalence of illegal fishing in the Australian Exclusive Economic Zone (EEZ), which has severely reduced shark numbers on reefs and shoals across a wide portion of the region surrounding Ashmore (Field et al. 2009). Furthermore, illegal fishing has declined dramatically across northern Australia waters since 2008 due to increased enforcement, suggesting an equal release of fishing pressure for all reefs in the region (Figure A.5). Immigration to Ashmore Reef may still have occurred if the habitat at this locality was in some way particularly attractive to sharks relative to other habitats nearby. Although our modelling showed that habitat explained $30 \%$ of the variance for shark abundance recorded by BRUVS at Ashmore Reef (Figure A.3) we found no significant differences in habitat categories between surveys. In both 2004 and 2016 areas that had reef structure (coral, rock, algae), generally had higher relative abundances of sharks than areas of sand, which is consistent with numerous studies (Barnett et al. 2012; Economakis and Lobel 1998; Espinoza et al. 2014; Field et al. 2011; McKibben and Nelson 1986; Speed et al. 2016). It also seems unlikely that habitat quality and prey availability was a driver of movement between Ashmore Reef and Cartier Reef, as average cover of hard coral (ca. 25\%) and fish community structures are very similar at both localities (Heyward et al. 2012).

Long-term (15 years) monitoring studies on the Scott Reefs and Rowley Shoals found no evidence that abundances of sharks and teleost mesopredators varied in response to very large changes in the composition of benthic communities (loss of $80 \%$ of coral cover) and the replacement of live coral by turfing algae, or during the process of recovery of coral habitats (Ruppert et al. 2013). Recent studies have shown that the differences in relative abundances of sharks between the unfished Rowley Shoals and the fished Scott Reefs have now remained unchanged for almost 20 years (Barley et al. 2017b; Ruppert et al. 2013), despite these reefs undergoing long cycles of disturbance and recovery in benthic communities during this time (Gilmour et al. 2013). This suggests that the increase in abundance we recorded at Ashmore Reef was not likely to be the result of "bottom-up" natural process of disturbance that improved the conditions for shark survivorship and growth through time. As mesopredators near the top of the food chain, abundances of reef sharks are more likely to be driven by "topdown" processes such as fishing and predation by apex species that consume these sharks (Lowe et al. 1996; Simpfendorfer et al. 2001; Stevens and Lyle 1989). 
At least in initial years after fishing had ceased at Ashmore Reef, recovery of reef sharks may have also benefited from a lack of apex predators through lower rates of predation ('mesopredator release' - e.g. Barley et al. 2017b; Myers et al. 2007; Ruppert et al. 2013) and access to resources that were otherwise too risky to exploit. There was an increase in the abundance of apex predators, notably G. cuvier at Ashmore Reef between $2004(n=0)$ and $2016(n=12)$, implying that numbers of this species also required time to rebound from fishing. Additionally, Sphyrna mokarran was also seen at Ashmore Reef in the 2016 survey, although it was not included our analysis as the BRUVS on which it was recorded turned upside down on deployment. The rapid recovery of reef sharks at Ashmore Reef may thus result from the synergistic effects of the eradication of fishing, reduced inter and intra-species competition and the reduction of predation pressure.

There was no evidence that the increase in abundance of sharks at Ashmore Reef between our surveys was simply a consequence of variation in sampling intensity or efficiency of the baited cameras. Numerous BRUVS surveys at Scott Reefs and the Rowley Shoals between 2004 and 2016 show that the contrast in relative abundance between these reef systems has been maintained irrespective of the spread of sampling sites within reefs and varying levels of replication (Barley et al. 2017a; Ruppert et al. 2013). This provides strong circumstantial evidence that the cessation of fishing was the primary driver of the differences in abundance we found between sampling years at Ashmore Reef. It is also unlikely that the relatively high abundances we recorded in 2016 were the result of an ephemeral aggregation of reef sharks at Ashmore Reef. Such aggregations are known to occur at small spatial scales, usually in response to a temporary increase in the abundance of prey such as schools of spawning fish in reef passes (Mourier et al. 2016), or in relation to reproductive activities (Economakis and Lobel 1998). However, our sampling at Ashmore was not spatially restricted and we found high abundances of reef sharks throughout a wide range of available habitats, suggesting that they did not occur in response to localised prey abundance. Although we sampled in the spring of 2004 and summer of 2016 at Ashmore, this is unlikely to have had an effect on MaxN (or additional metrics - Figure A.6), as there is little evidence to support the suggestion that differences in reef attendance of $C$. amblyrhynchos at isolated reefs (Barnett et al. 2012; Field et al. 2011) can be explained by seasonal or environmental drivers (Espinoza et al. 2015; Heupel and Simpfendorfer 2014).

We suggest that the shark assemblage at Ashmore Reef has returned to a near-unfished state, based on a comparison of abundances and composition with the assemblage of sharks at the Rowley Shoals. The Rowley Shoals is one of the very few examples of a reef system in the eastern Indian Ocean that is relatively unexploited and where MPA status has been strictly enforced and verified by management agencies for almost three decades. The current trophic composition of sharks at Ashmore Reef and the Rowley Shoals are also similar in structure to no-take zones on the Great Barrier Reef (Figure A.7 - reproduced from Espinoza et al. 2014). In reality however, the potential for shifting baselines (Knowlton and Jackson 2008) compromises any assertion that the Rowley Shoals reef system represents a "pristine" state for shark assemblages (i.e. without anthropogenic influences). Warming seawater temperatures, ocean acidification (Hughes et al. 2003) and pollution of marine food chains by plastics are global phenomena and their effects on shark assemblages are largely unstudied in the Indian Ocean (Cliff et al. 2002). Furthermore, recent research shows that apex species such as tiger sharks move along the entire coastline and shelf of Western Australia. In so doing, they traverse multiple management regimes and enter waters beyond coral reef no-take MPAs where they are susceptible to fishing and other anthropogenic threats (Ferreira et al. 2015) that are likely to impact on population status (Simpfendorfer 2009). Reduced abundances of these keystone species are likely to have profound effects on the lower trophic 
levels of food chains (Ferretti et al. 2010; Heithaus et al. 2008). Thus, the Rowley Shoals can only be considered as a "baseline" in the context of oceanic and shelf ecosystems that are evolving in response to human activities.

\section{Conclusion}

Our results show that the establishment of even a relatively small no-take MPA $\left(583 \mathrm{~km}^{2}\right)$ can aid the recovery of shark communities. Most importantly, comparisons across other reef systems in the region show that recovery has occurred throughout the trophic structure, including apex species. Separation of the shark assemblage into trophic levels also revealed a decline in the proportion of lower trophic level species, implying that removal of larger, toporder species allowed some elements of the shark assemblage to increase in abundance, altering trophic organisation within the shark assemblage. Given that enforcement is a key factor underlying the success of an MPA (Edgar et al. 2014; Gill et al. 2017), the presence of a management agency vessel on the reef and a decline in illegal fishing are likely to have combined to ensure recovery. The reduction in illegal fishing pressure due to enforcement was also likely to be aided by increasing fuel prices for fishermen (Sumaila et al. 2006), changes made to policies surrounding IUU fishing (Vince 2007), and reductions in target species on nearby reefs (Field et al. 2009). Overall, our study shows that well-managed notake MPAs can foster the recovery of shark communities at all trophic levels and at rates far greater than predicted by current models of population growth, implying the action of compensatory processes in recovery.

\section{Acknowledgements}

This work is contribution \#1 of the Global FinPrint Project, funded by Paul G. Allen Philanthropies. Additional support was provided by the Australian Institute of Marine Science. Data were collected under permits from the Department of Parks and Wildlife (Reg. 17-01-000023-1) and the Department of Environment (CMR-15-000360). We thank the following people for help with field work: A. Parr, M. Tropiano, J. Williams, W. Kelly, K. Osborne, H. Davies, M. Cundy, P. Thomson, T. Shalders, I. Lindgren, K. Cure, E. Lester, M. Ashbolt, S. Chapman, B. Walker, and J. van den Broek. We also thank J. Seager for his advice and assistance with EventMeasure and A. Mason for his contribution to video analyses. 


\section{References}

AFMA, 2013. Australian Fisheries Management Authority Annual Report 2012-13. Australian Government - Australian Fisheries Management Authority.

AFMA, 2014. Australian Fisheries Management Authority Annual Report 2013-14. Australian Government - Australian Fisheries Management Authority.

AFMA, 2015. Australian Fisheries Management Authority Annual Report 2014-15. Australian Government - Australian Fisheries Management Authority.

AFMA, 2016. Australian Fisheries Management Authority Annual Report 2015-16. Australian Government - Australian Fisheries Management Authority.

Agresti, A., 1996. An introduction to categorical data analysis. Wiley New York.

Australia, C.o., 2002. Ashmore Reef National Nature Reserve and Cartier Island Marine Reserve (Commonwelath Waters) Management Plans, Canberra.

Barley, S.C., Meekan, M.G., Meeuwig, J.J., 2017a. Diet and condition of mesopredators on coral reefs in relation to shark abundance. PloS one 12, e0165113.

Barley, S.C., Meekan, M.G., Meeuwig, J.J., 2017b. Species diversity, abundance, biomass, size and trophic structure of fish on coral reefs in relation to shark abundance. Marine Ecology Progress Series 565, 163-179.

Barnett, A., Abrantes, K.G., Seymour, J., Fitzpatrick, R., 2012. Residency and spatial use by reef sharks of an isolated seamount and its implications for conservation. PloS one 7 , e36574.

Bartoń, K., 2013. MuMIn: Multi-model inference. R package version 1.9. 13. The Comprehensive R Archive Network (CRAN), Vienna, Austria.

Berry, P., 1986. Faunal Surveys of the Rowley Shoals, Scott Reef, and Seringapatam Reef: North-western Australia. Western Australian Museum.

Berry, P., 1993. Marine faunal surveys of Ashmore Reef and Cartier Island north-western Australia. Western Australian Museum.

Bond, M.E., Babcock, E.A., Pikitch, E.K., Abercrombie, D.L., Lamb, N.F., Chapman, D.D., 2012. Reef sharks exhibit site-fidelity and higher relative abundance in marine reserves on the mesoamerican barrier reef. PloS one 7, e32983.

Bradley, D., Conklin, E., Papastamatiou, Y.P., McCauley, D.J., Pollock, K., Pollock, A., Kendall, B.E., Gaines, S.D., Caselle, J.E., 2017. Resetting predator baselines in coral reef ecosystems. Scientific reports 7.

Breheny, P., Burchett, W., 2013. Visualization of regression models using visreg. R Package, $1-15$.

Brunnschweiler, J.M., 2010. The Shark Reef Marine Reserve: a marine tourism project in Fiji involving local communities. Journal of Sustainable Tourism 18, 29-42.

Burnham, K.P., Anderson, D.R., 2002. Model Selection and Multimodal Inference: A Practical Information-Theoretic Approach, 2nd edn. Springer-Verlag, New York, USA.

Carlson, J.K., Baremore, I.E., 2003. Changes in biological parameters of Atlantic sharpnose shark Rhizoprionodon terraenovae in the Gulf of Mexico: evidence for densitydependent growth and maturity? Marine and Freshwater Research 54, 227-234.

Chapman, D.D., Frisk, M.J., Abercrombie, D.L., Safina, C., Gruber, S.H., Babcock, E.A., Feldheim, K.A., Pikitch, E.K., Ward-Paige, C., Davis, B., 2013. Give shark sanctuaries a chance. Science (New York, NY) 339, 757-757.

Clarke, S.C., McAllister, M.K., Milner-Gulland, E.J., Kirkwood, G., Michielsens, C.G., Agnew, D.J., Pikitch, E.K., Nakano, H., Shivji, M.S., 2006. Global estimates of shark catches using trade records from commercial markets. Ecology Letters 9, 1115-1126. 
Cliff, G., Dudley, S.F., Ryan, P.G., Singleton, N., 2002. Large sharks and plastic debris in KwaZulu-Natal, South Africa. Marine and Freshwater Research 53, 575-581.

Conservation, D.o.E.a., 2007. Rowley Shoals Marine Park Management Plan 2007-2017 Management Plan No. 56, Perth, Western Australia.

Cortes, E., 2000. Life history patterns and correlations in sharks. Reviews in Fisheries Science 8, 299-344.

Cortes, E., 2002. Incorporating uncertainty into demographic modeling: application to shark populations and their conservation. Conservation Biology 16, 1048-1062.

Davidson, L.N.K., 2012. Shark sanctuaries: substance or spin? Science 21, 1538.

DIBP, 2017. Australian Border Force Cutter (ABFC) Thaiyak.

Dulvy, N.K., 2006. Conservation biology: strict marine protected areas prevent reef shark declines. Current Biology 16, 989-991.

Dulvy, N.K., Freckleton, R.P., Polunin, N.V., 2004. Coral reef cascades and the indirect effects of predator removal by exploitation. Ecology Letters 7, 410-416.

Economakis, A.E., Lobel, P.S., 1998. Aggregation behavior of the grey reef shark, Carcharhinus amblyrhynchos, at Johnston Atoll, Central Pacific Ocean. Environmental Biology of Fishes 51, 129-139.

Edgar, G.J., Stuart-Smith, R.D., Willis, T.J., Kininmonth, S., Baker, S.C., Banks, S., Barrett, N.S., Becerro, M.A., Bernard, A.T., Berkhout, J., 2014. Global conservation outcomes depend on marine protected areas with five key features. Nature 506, 216220.

Ellis, D., DeMartini, E., 1995. Evaluation of a video camera technique for indexing abundances of juvenile pink snapper, Pristipomoides filamentosus, and other Hawaiian insular shelf fishes. Oceanographic Literature Review 9, 786.

Espinoza, M., Cappo, M., Heupel, M.R., Tobin, A.J., Simpfendorfer, C.A., 2014. Quantifying shark distribution patterns and species-habitat associations: implications of marine park zoning.

Espinoza, M., Heupel, M.R., Tobin, A.J., Simpfendorfer, C.A., 2015. Residency patterns and movements of grey reef sharks (Carcharhinus amblyrhynchos) in semi-isolated coral reef habitats. Marine Biology 162, 343-358.

Ferreira, L.C., Thums, M., Meeuwig, J.J., Vianna, G.M., Stevens, J., McAuley, R., Meekan, M.G., 2015. Crossing latitudes - long-distance tracking of an apex predator. PloS one 10, e0116916.

Ferretti, F., Worm, B., Britten, G.L., Heithaus, M.R., Lotze, H.K., 2010. Patterns and ecosystem consequences of shark declines in the ocean. Ecology Letters 13, 10551071.

Field, I.C., Meekan, M.G., Buckworth, R.C., Bradshaw, C.J.A., 2009. Protein mining the world's oceans: Australasia as an example of illegal expansion-and displacement fishing. Fish and Fisheries 10, 323-328.

Field, I.C., Meekan, M.G., Speed, C.W., White, W., Bradshaw, C.J.A., 2011. Quantifying movement patterns for shark conservation at remote coral atolls in the Indian Ocean. Coral reefs 30, 61-71.

Gallagher, A.J., Hammerschlag, N., 2011. Global shark currency: the distribution, frequency, and economic value of shark ecotourism. Current Issues in Tourism 14, 797-812.

Gill, D.A., Mascia, M.B., Ahmadia, G.N., Glew, L., Lester, S.E., Barnes, M., Craigie, I., Darling, E.S., Free, C.M., Geldmann, J., 2017. Capacity shortfalls hinder the performance of marine protected areas globally. Nature 543, 665-669.

Gilmour, J.P., Smith, L.D., Heyward, A.J., Baird, A.H., Pratchett, M.S., 2013. Recovery of an isolated coral reef system following severe disturbance. Science 340, 69-71. 
Graham, N.A., Spalding, M.D., Sheppard, C.R., 2010. Reef shark declines in remote atolls highlight the need for multi-faceted conservation action. Aquatic Conservation: Marine and Freshwater Ecosystems 20, 543-548.

Harvey, E., Shortis, M., Stadler, M., Cappo, M., 2002. A comparison of the accuracy and precision of measurements from single and stereo-video systems. Marine Technology Society Journal 36, 38-49.

Heithaus, M.R., Frid, A., Vaudo, J.J., Worm, W., Wirsing, A.J., 2010. Unraveling the ecological importance of elasmobranchs, In Sharks and their relatives II-Biodiversity, adaptive physiology, and conservation. eds J.C. Carrier, J.A. Musick, M.R. Heithaus. CRC Press, Boca Raton.

Heithaus, M.R., Frid, A., Wirsing, A.J., Worm, B., 2008. Predicting ecological consequences of marine top predator declines. Trends in Ecology and Evolution 23, 202-210.

Heupel, M., Simpfendorfer, C., 2014. Importance of environmental and biological drivers in the presence and space use of a reef-associated shark. Marine Ecology Progress Series 496, 47-57.

Heupel, M.R., Knip, D.M., Simpfendorfer, C.A., Dulvy, N.K., 2014. Sizing up the ecological role of sharks as predators. Marine Ecology Progress Series 495, 291-298.

Heupel, M.R., Simpfendorfer, C.A., Fitzpatrick, R., 2010. Large-scale movement and reef fidelity of grey reef sharks. PloS one 5, 1-5.

Heyward, A., Jones, R., Travers, M., Burns, K., Suosaari, G., Colquhoun, J., Case, M., Radford, B., Meekan, M., Markey, K., 2012. Montara: 2011 Shallow Reef Surveys at Ashmore, Cartier and Seringapatam Reefs. Australian Institute of Marine Science, Townsville, Qld.

Hisano, M., Connolly, S.R., Robbins, W.D., 2011. Population growth rates of reef sharks with and without fishing on the Great Barrier Reef: robust estimation with multiple models. PloS one 6, e25028.

Holden, M., 1973. Are long-term sustainable fisheries for elasmobranchs possible. Fish stocks and recruitment. Rapports et Proces-Verbaux des Reunions Conseil International pour l'Exploration de la Mer 164, 360-367.

Hughes, T.P., Baird, A.H., Bellwood, D.R., Card, M., Connolly, S.R., Folke, C., Grosberg, R., Hoegh-Guldberg, O., Jackson, J., Kleypas, J., 2003. Climate change, human impacts, and the resilience of coral reefs. Science 301, 929-933.

Hussey, N.E., DiBattista, J.D., Moore, J.W., Ward, E.J., Fisk, A.T., Kessel, S., Guttridge, T.L., Feldheim, K.A., Franks, B.R., Gruber, S.H., 2017. Risky business for a juvenile marine predator? Testing the influence of foraging strategies on size and growth rate under natural conditions, In Proc. R. Soc. B. p. 20170166. The Royal Society.

Huveneers, C., Meekan, M.G., Ferreira, L.C., Pannell, D., Vianna, G.M.S., 2017. The economic value of shark-diving tourism in Australia. Reviews in Fish Biology and Fisheries.

Jackman, S., Fearon, J., Jackman, M.S., MCMCpack, S., 2007. The pscl package. Soware. http://cran. rproject. org/src/contrib/Descriptions/pscl. html.

Knowlton, N., Jackson, J.B., 2008. Shifting baselines, local impacts, and global change on coral reefs. PLoS Biol 6, e54.

Lowe, C.G., Wetherbee, B.M., Crow, G.L., Tester, A.L., 1996. Ontogenetic dietary shifts and feeding behavior of the tiger shark, Galeocerdo cuvier, in Hawaiian waters. Environmental Biology of Fishes 47, 203-211.

Malcolm, H.A., Jordan, A., Smith, S.D., 2011. Testing a depth-based Habitat Classification System against reef fish assemblage patterns in a subtropical marine park. Aquatic Conservation: Marine and Freshwater Ecosystems 21, 173-185. 
Marshall, L.J., 2011. The fin blue line: Quantifying fishing mortality using shark fin morphology. University of Tasmania.

McKibben, J.N., Nelson, D.R., 1986. Patterns of movement and grouping of gray reef sharks, Carcharhinus amblyrhynchos, at Enewetak, Marshall Island. Bulletin of Marine Science 38, 89-110.

Meekan, M.M., Cappo, M.M., Carleton, J.J., Marriott, R.R., 2006. Surveys of shark and finfish abundance on reefs within the MOU74 Box and Rowleys Shoals using baited remote underwater video systems. Prepared for the Australian Government Department of the Environment and Heritage.

Momigliano, P., Harcourt, R., Robbins, W., Jaiteh, V., Mahardika, G., Sembiring, A., Stow, A., 2017. Genetic structure and signatures of selection in grey reef sharks (Carcharhinus amblyrhynchos). Heredity.

Mourier, J., Maynard, J., Parravicini, V., Ballesta, L., Clua, E., Domeier, M.L., Planes, S., 2016. Extreme inverted trophic pyramid of reef sharks supported by spawning groupers. Current Biology 26, 2011-2016.

Myers, R.A., Baum, J.K., Shepard, T.D., Powers, S.P., Peterson, C.H., 2007. Cascading Effects of the Loss of Apex Predatory Sharks from a Coastal Ocean. Science 315.

Nadon, M.O., Baum, J.K., Williams, I.D., McPherson, J.M., Zgliczynski, B.J., Richards, B.L., Schroeder, R.E., Brainard, R.E., 2012. Re-Creating Missing Population Baselines for Pacific Reef Sharks. Conservation Biology 26, 493-503.

Newton, K., Cote, I.M., Pilling, G.M., Jennings, S., Dulvy, N.K., 2007. Current and future sustainability of island coral reef fisheries. Current Biology 17, 655-658.

Radtke, R., Cailliet, G., 1984. Age estimation and growth of the gray reef shark Carcharhinus amblyrhynchos from the northwestern Hawaiian Islands, In Proceedings of the Second Symposium on Resource Investigations of the NW Hawaiian Islands. pp. 121-127.

Robbins, W.D., 2006. Abundance, demography and population structure of the grey reef shark (Carcharhinus amblyrhynchos) and the white tip reef shark (Triaenodon obesus)(Fam. Charcharhinidae). James Cook University.

Robbins, W.D., Hisano, M., Connolly, S.R., Choat, H.J., 2006. Ongoing Collapse of CoralReef Shark Populations. Current Biology 16, 2314-2319.

Roff, G., Doropoulos, C., Rogers, A., Bozec, Y.-M., Krueck, N.C., Aurellado, E., Priest, M., Birrell, C., Mumby, P.J., 2016. The ecological role of sharks on coral reefs. Trends in Ecology \& Evolution 31, 395-407.

Ruppert, J.L., Travers, M.J., Smith, L.L., Fortin, M.-J., Meekan, M.G., 2013. Caught in the middle: combined impacts of shark removal and coral loss on the fish communities of coral reefs.

Russell, B.C., Vail, L.L., 1988. Report on traditional Indonesian fishing activities at Ashmore Reef Nature Reserve. Australian National Parks and Wildlife Service and Northern Territory Museum of Arts and Sciences.

Simpfendorfer, C., 2009. Galeocerdo cuvier. IUCN 2011. IUCN Red List of Threatened Species. Version 20112.

Simpfendorfer, C.A., Goodreid, A.B., McAuley, R.B., 2001. Size, sex and geographic variation in the diet of the tiger shark, Galeocerdo cuvier, from Western Australian waters. Environmental Biology of Fishes 61, 37-46.

Smart, J.J., Chin, A., Baje, L., Green, M.E., Appleyard, S.A., Tobin, A.J., Simpfendorfer, C.A., White, W.T., 2016. Effects of Including Misidentified Sharks in Life History Analyses: A Case Study on the Grey Reef Shark Carcharhinus amblyrhynchos from Papua New Guinea. PloS one 11, e0153116. 
Smith, S.E., Au, D.W., Show, C., 1998. Intrinsic rebound potentials of 26 species of Pacific sharks. Marine and Freshwater Research 49, 663-678.

Speed, C., Meekan, M., Field, I., McMahon, C., Harcourt, R., Stevens, J., Babcock, R., Pillans, R., Bradshaw, C., 2016. Reef shark movements relative to a coastal marine protected area. Regional Studies in Marine Science 3, 58-66.

Stevens, J., Lyle, J., 1989. Biology of three hammerhead sharks (Eusphyra blochii, Sphyrna mokarran and S. lewini) from northern Australia. Marine and Freshwater Research 40, 129-146.

Stevens, J.D., McLoughlin, K.J., 1991. Distribution, Size and Sex Composition, Reproductive Biology and Diet of Sharks from Northern Australia. Australian Journal of Marine and Freshwater Research 32, 151-199.

Sumaila, U.R., Alder, J., Keith, H., 2006. Global scope and economics of illegal fishing. Marine Policy 30, 696-703.

Tickler, D.M., Letessier, T.B., Koldewey, H.J., Meeuwig, J.J., 2017. Drivers of abundance and spatial distribution of reef-associated sharks in an isolated atoll reef system. PloS one 12 , e0177374.

Venables, W.N., Ripley, B.D., 2002. Random and mixed effects, In Modern applied statistics with S. pp. 271-300. Springer.

Vianna, G., Meekan, M., Pannell, D., Marsh, S., Meeuwig, J., 2012. Socio-economic value and community benefits from shark-diving tourism in Palau: A sustainable use of reef shark populations. Biological Conservation.

Vince, J., 2007. Policy responses to IUU fishing in Northern Australian waters. Ocean \& Coastal Management 50, 683-698.

Walsh, C., Mac Nally, R., Walsh, M.C., 2003. The hier. part package. Hierarchical Partitioning. R project for statistical computing. URL: http://cran. r-project. org.

Ward-Paige, C.A., 2017. A global overview of shark sanctuary regulations and their impact on shark fisheries. Marine Policy 82, 87-97.

Ward-Paige, C., Keith, D., Worm, B., Lotze, H.K., 2012. Recovery potential and conservation options for elasmobranchs. Journal of Fish Biology 80, 1844-1869.

Wetherbee, B.M., Crow, G.L., Lowe, C.G., 1997. Distribution, reproduction and diet of the gray reef shark Carcharhinus amblyrhynchos in Hawaii. Marine Ecology Progress Series 151, 181-189.

White, T.D., Carlisle, A.B., Kroodsma, D.A., Block, B.A., Casagrandi, R., De Leo, G.A., Gatto, M., Micheli, F., McCauley, D.J., 2017. Assessing the effectiveness of a large marine protected area for reef shark conservation. Biological Conservation 207, 6471.

Willis, T.J., Babcock, R.C., 2000. A baited underwater video system for the determination of relative density of carnivorous reef fish. Marine and Freshwater Research 51, 755763.

Wilson, B., 2013. The biogeography of the Australian North West Shelf: environmental change and life's response. Newnes.

Wilson, S., Graham, N., Polunin, N., 2007. Appraisal of visual assessments of habitat complexity and benthic composition on coral reefs. Marine Biology 151, 1069-1076.

Worm, B., Davis, B., Kettemer, L., Ward-Paige, C.A., Chapman, D., Heithaus, M.R., Kessel, S.T., Gruber, S.H., 2013. Global catches, exploitation rates, and rebuilding options for sharks. Marine Policy 40, 194-204.

Zuur, A., Ieno, E.N., Smith, G.M., 2007. Analyzing ecological data. Springer Science \& Business Media.

Zuur, A.F., Ieno, E.N., Walker, N.J., Saveliev, A.A., Smith, G.M., 2009. Mixed Effects Models and Extensions in Ecology with R. Springer, Berlin. 


\section{Tables and figures}

Table 1. Deployment locations and depths of Baited Remote Underwater Video Stations (BRUVS) in north-western Australia. Data were collected at Ashmore Reef in October 2004 and January 2016, and Scott Reefs and Rowley Shoals in September 2016.

\begin{tabular}{|c|c|c|c|c|}
\hline & $\mathbf{2 0 0 4}$ & \multicolumn{3}{|c|}{$\mathbf{2 0 1 6}$} \\
\hline Depth range (m) & Ashmore Reef & Ashmore Reef & Rowley Shoals & Scott Reefs \\
\hline$<10$ & 0 & 11 & 14 & 19 \\
10 to 19 & 8 & 12 & 30 & 77 \\
20 to 29 & 17 & 26 & 5 & 1 \\
30 to 39 & 5 & 36 & 6 & 0 \\
$40-49$ & 7 & 4 & 2 & 0 \\
$>50$ & 9 & 0 & 0 & 0 \\
\hline \hline Total & $\mathbf{4 6}$ & $\mathbf{8 9}$ & $\mathbf{5 7}$ & $\mathbf{9 7}$ \\
\hline
\end{tabular}




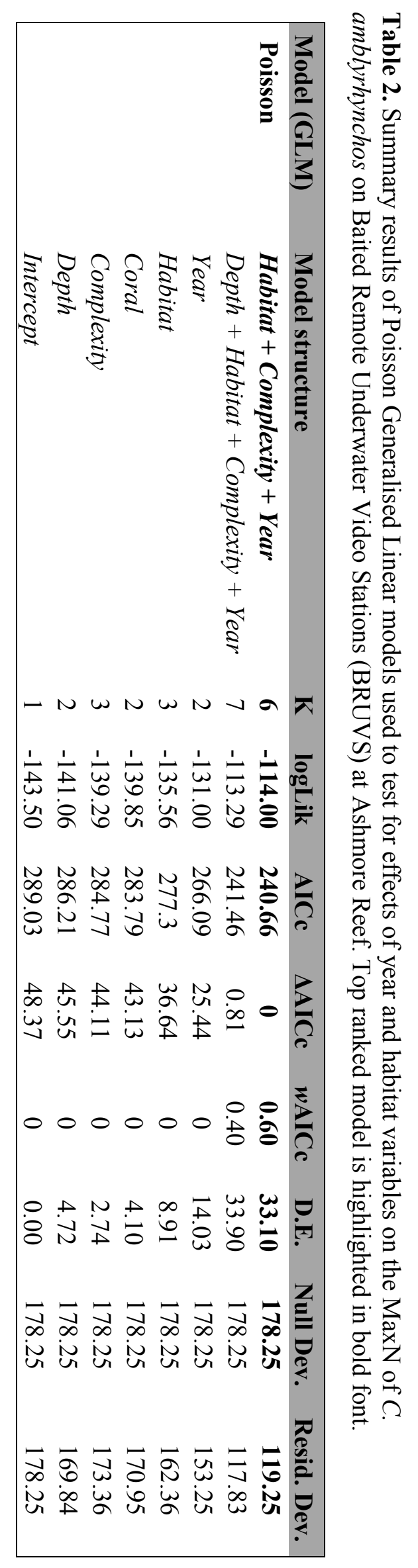




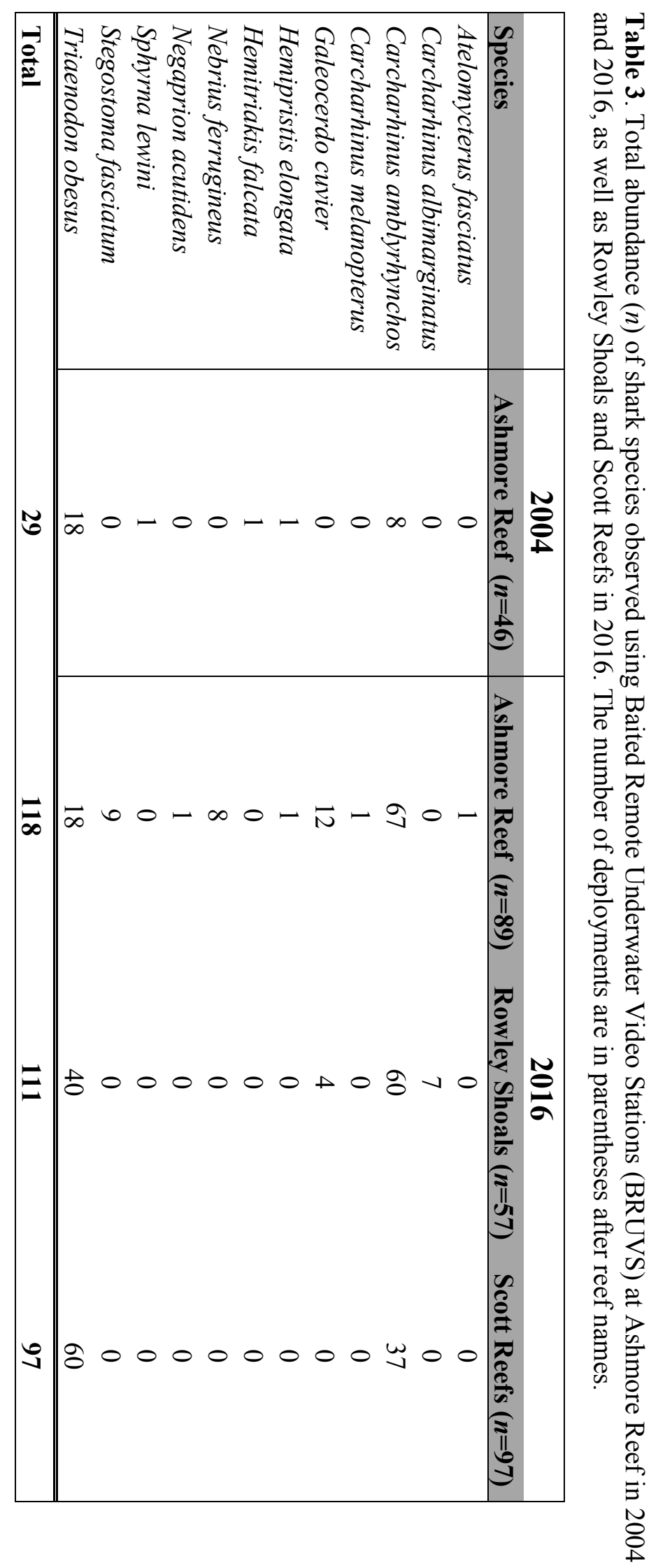




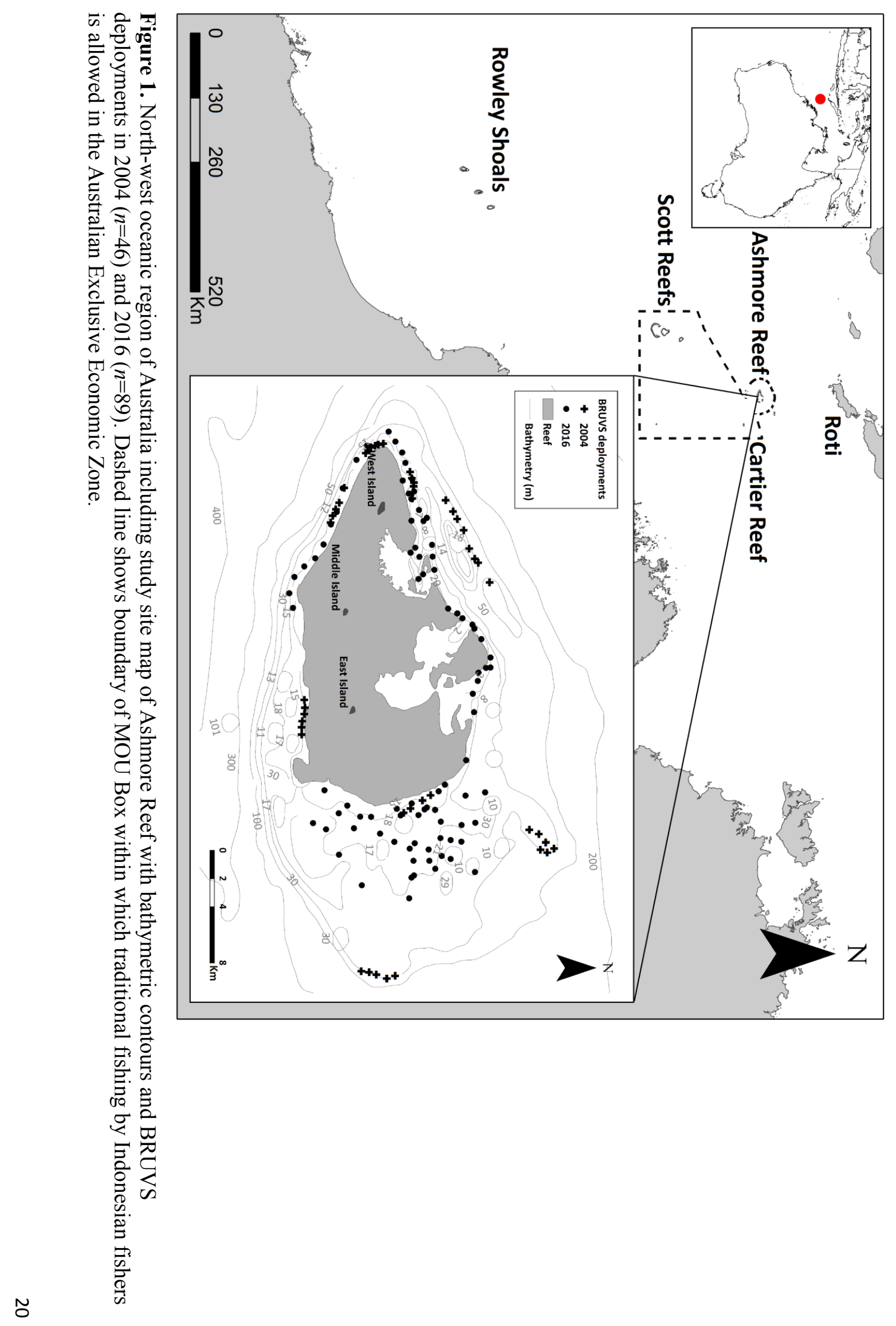




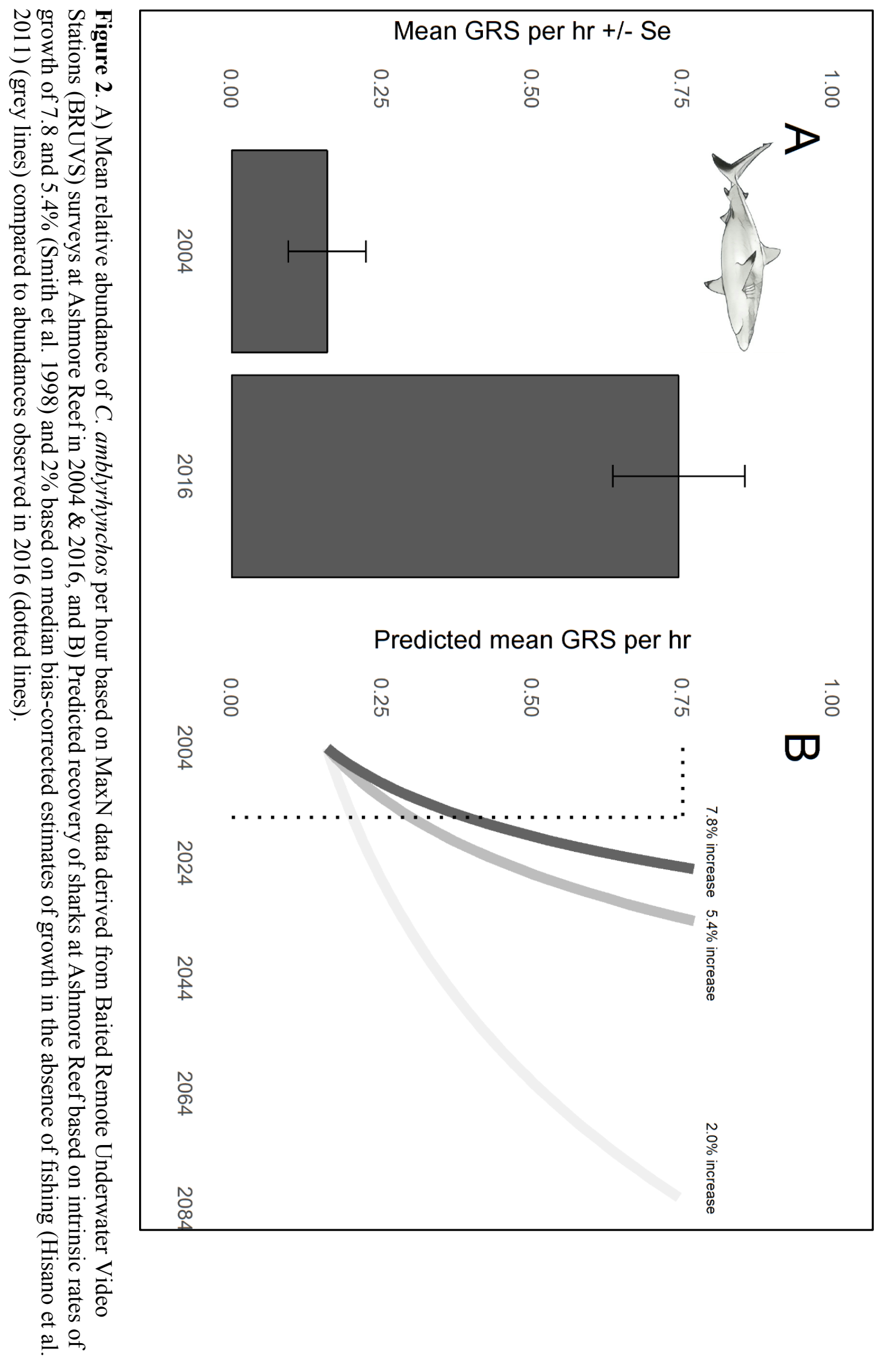



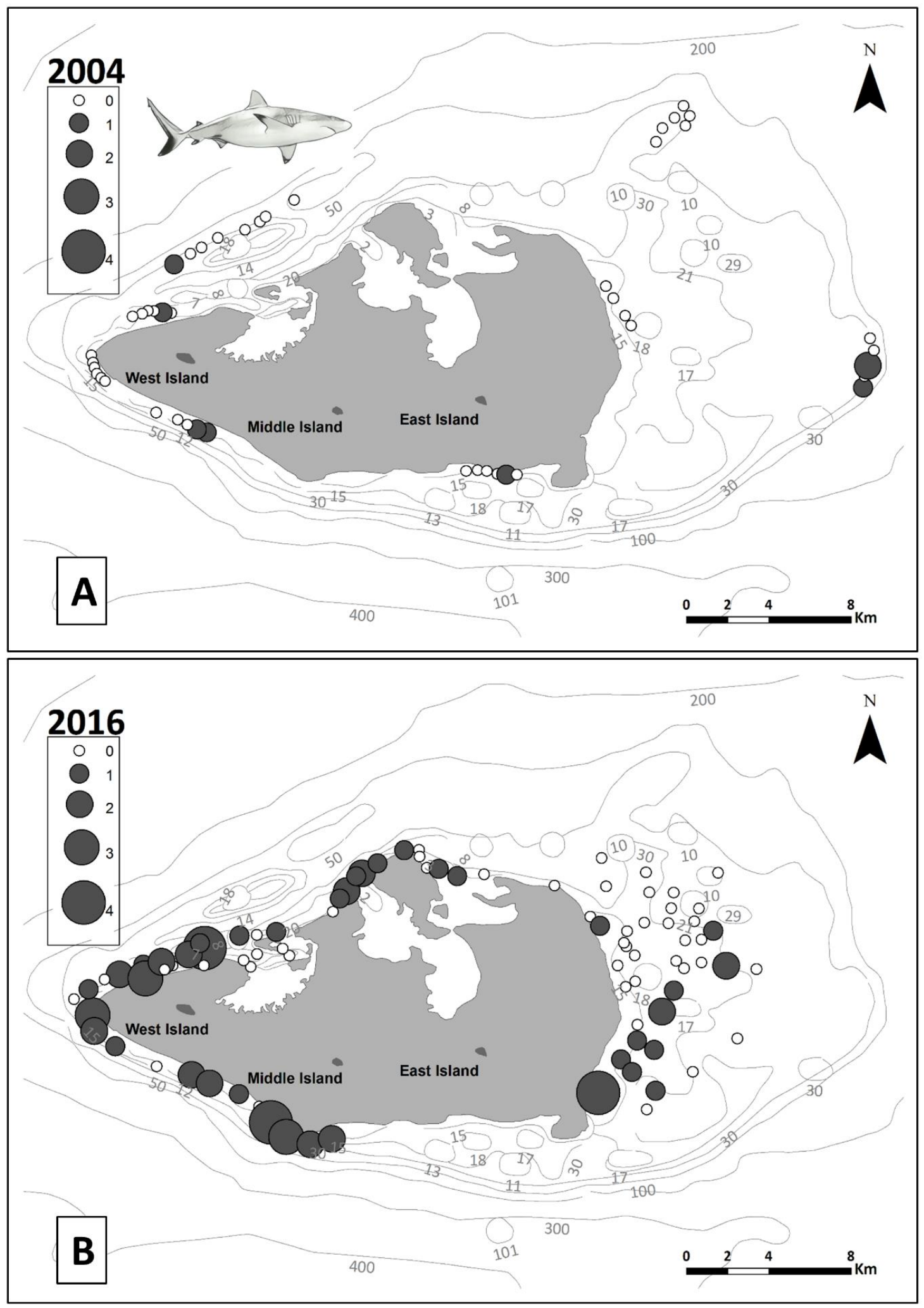

Figure 3. Distribution and MaxN of C. amblyrhynchos at Ashmore Reef based on Baited Remote Underwater Video Stations (BRUVS) surveys conducted in A) $2004(n=46)$ and B) $2016(n=89)$. 


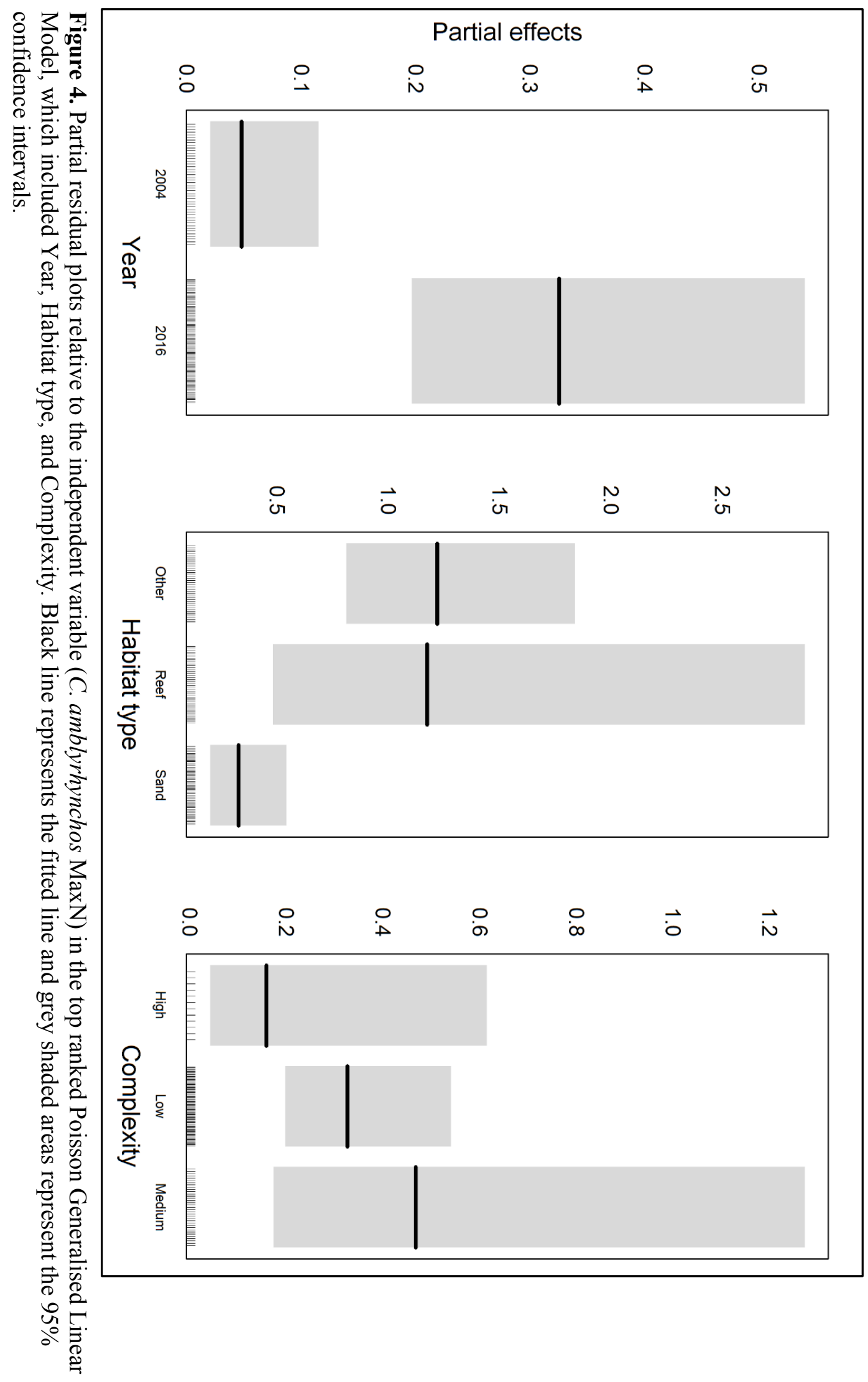




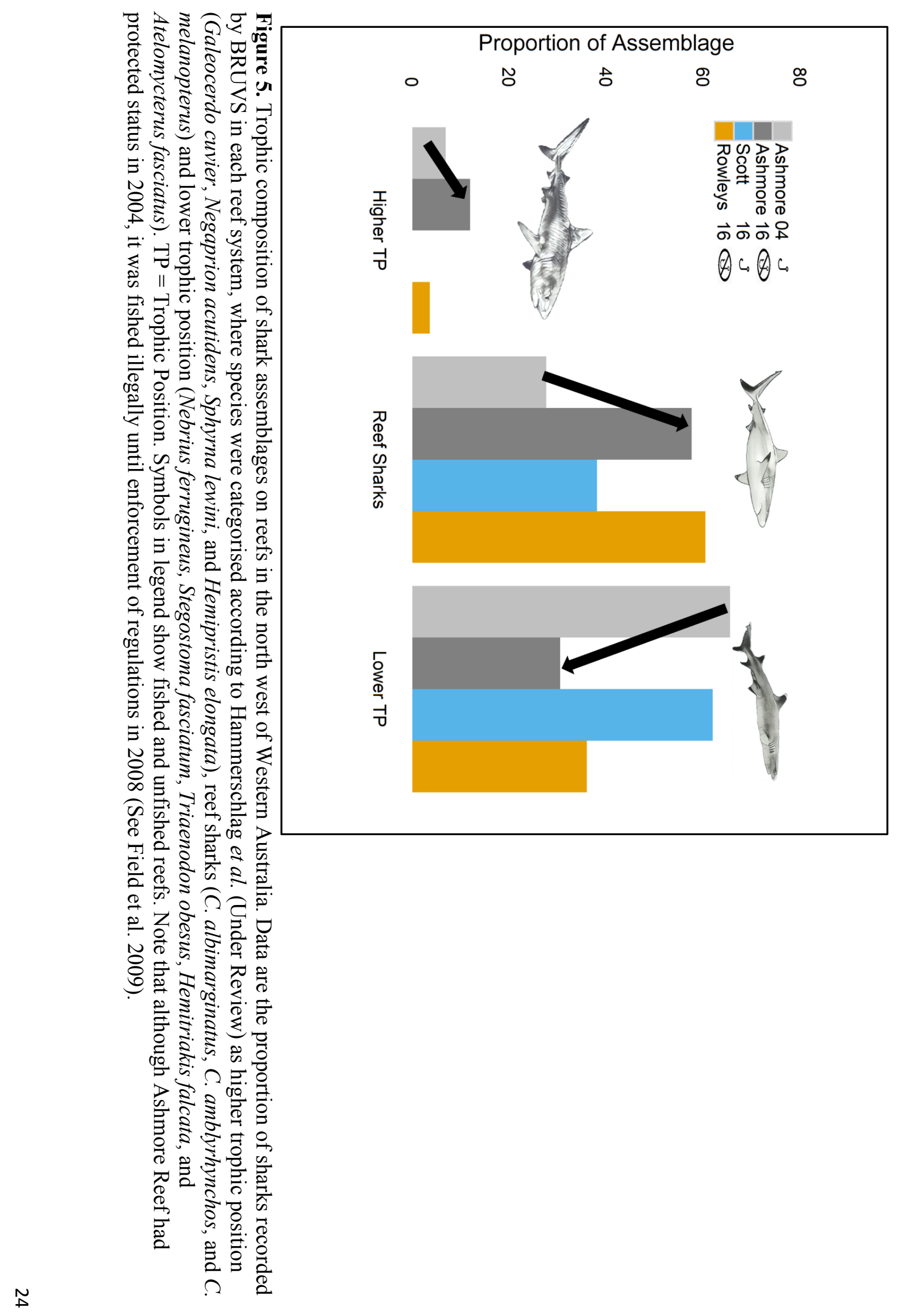




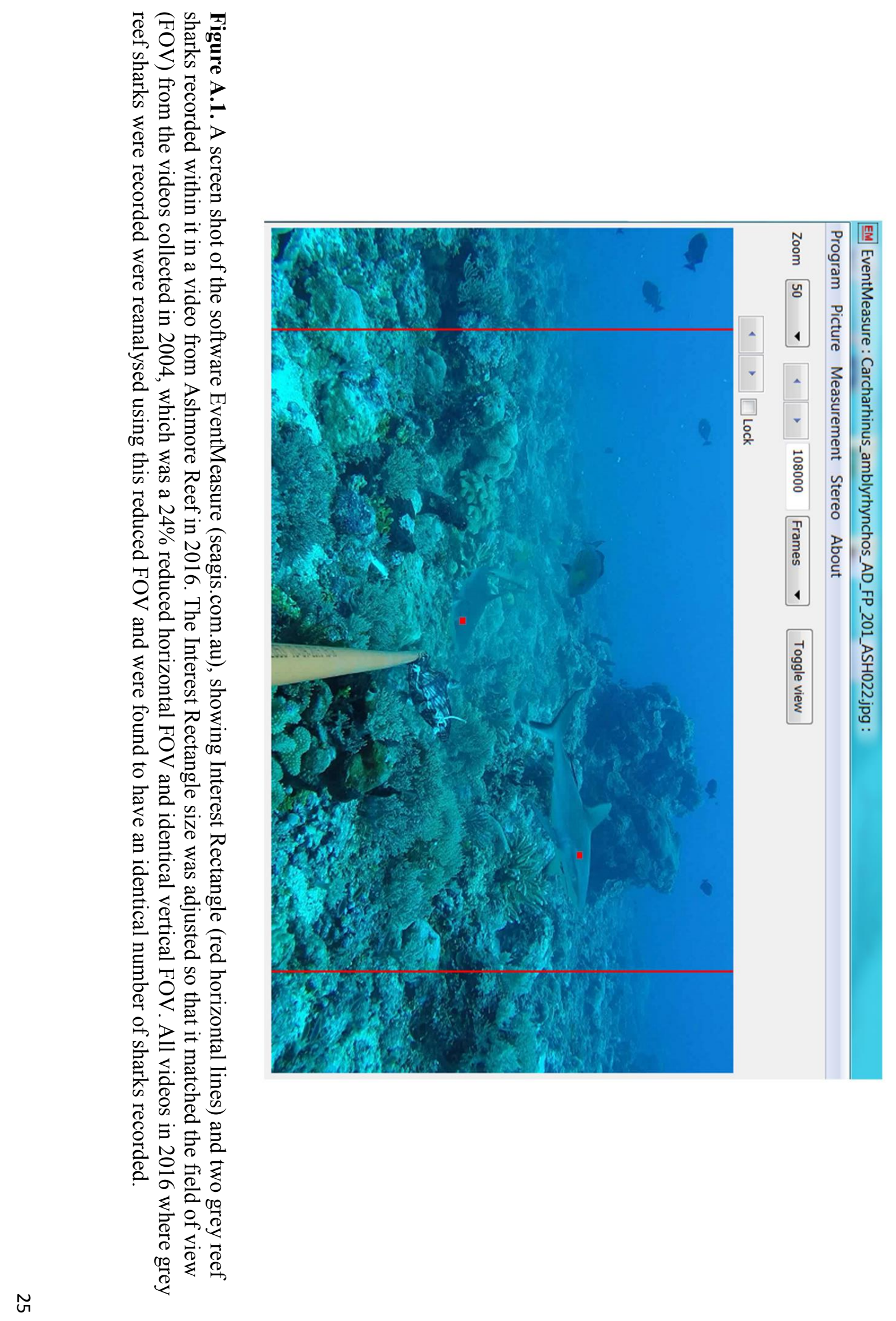




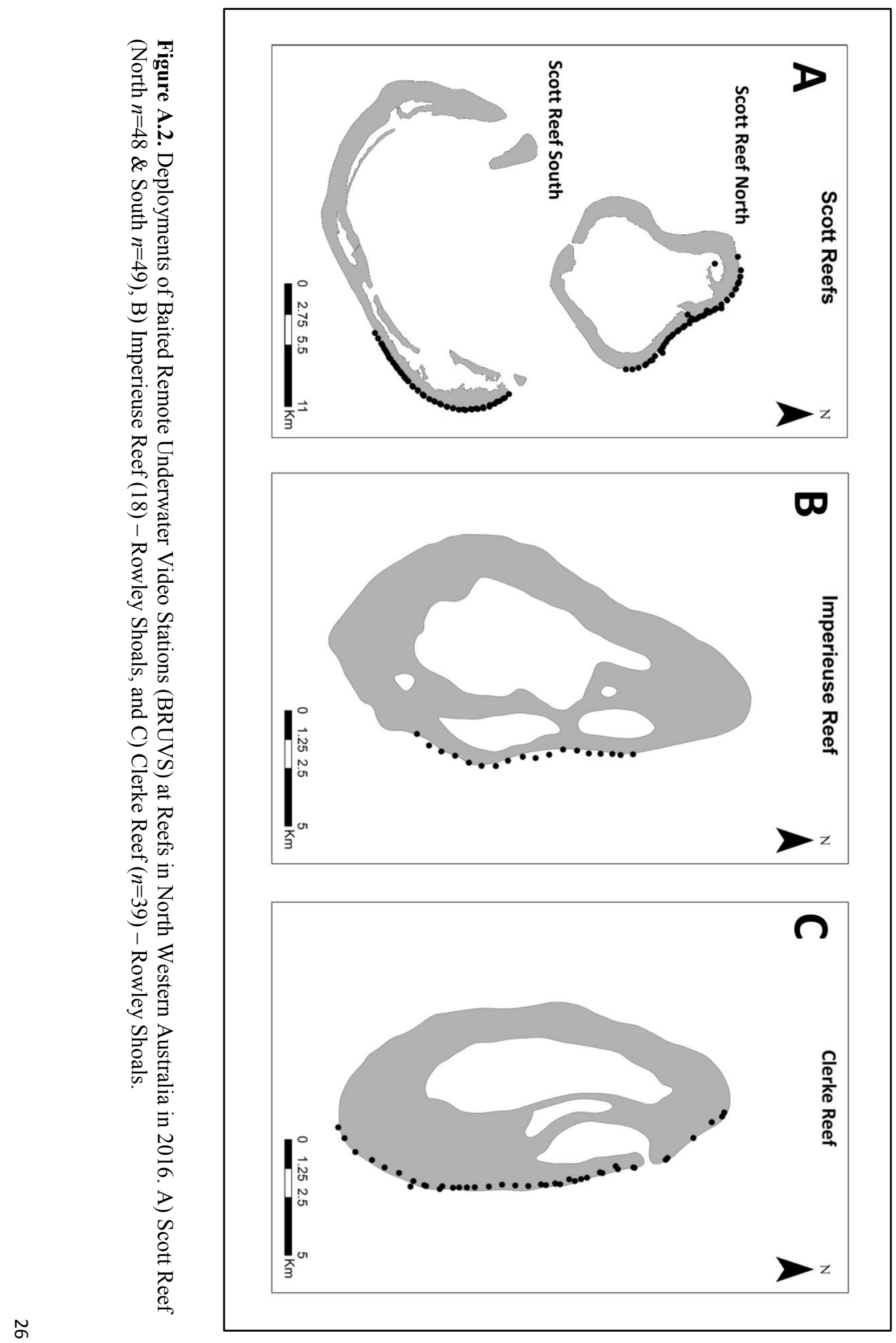




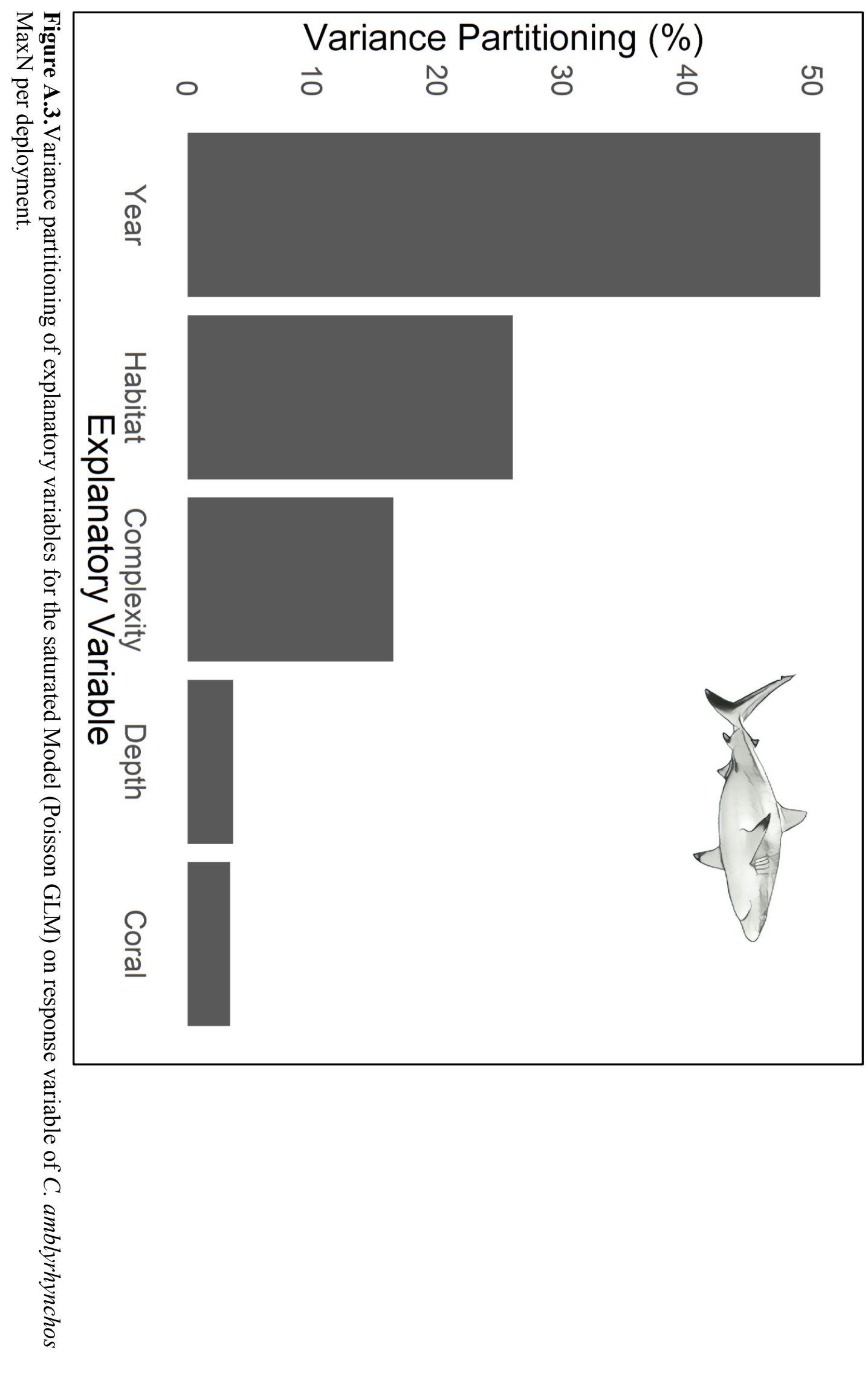




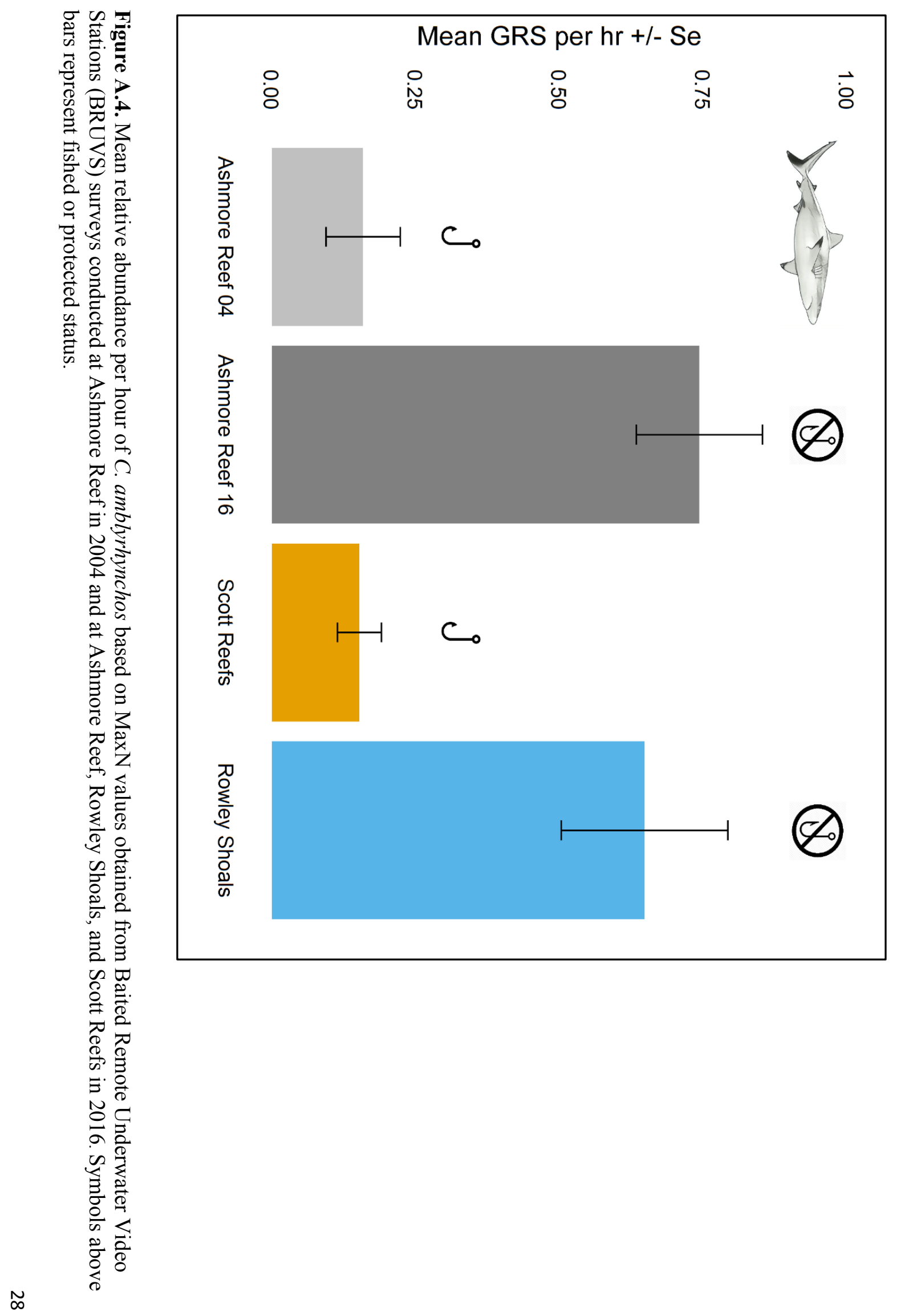




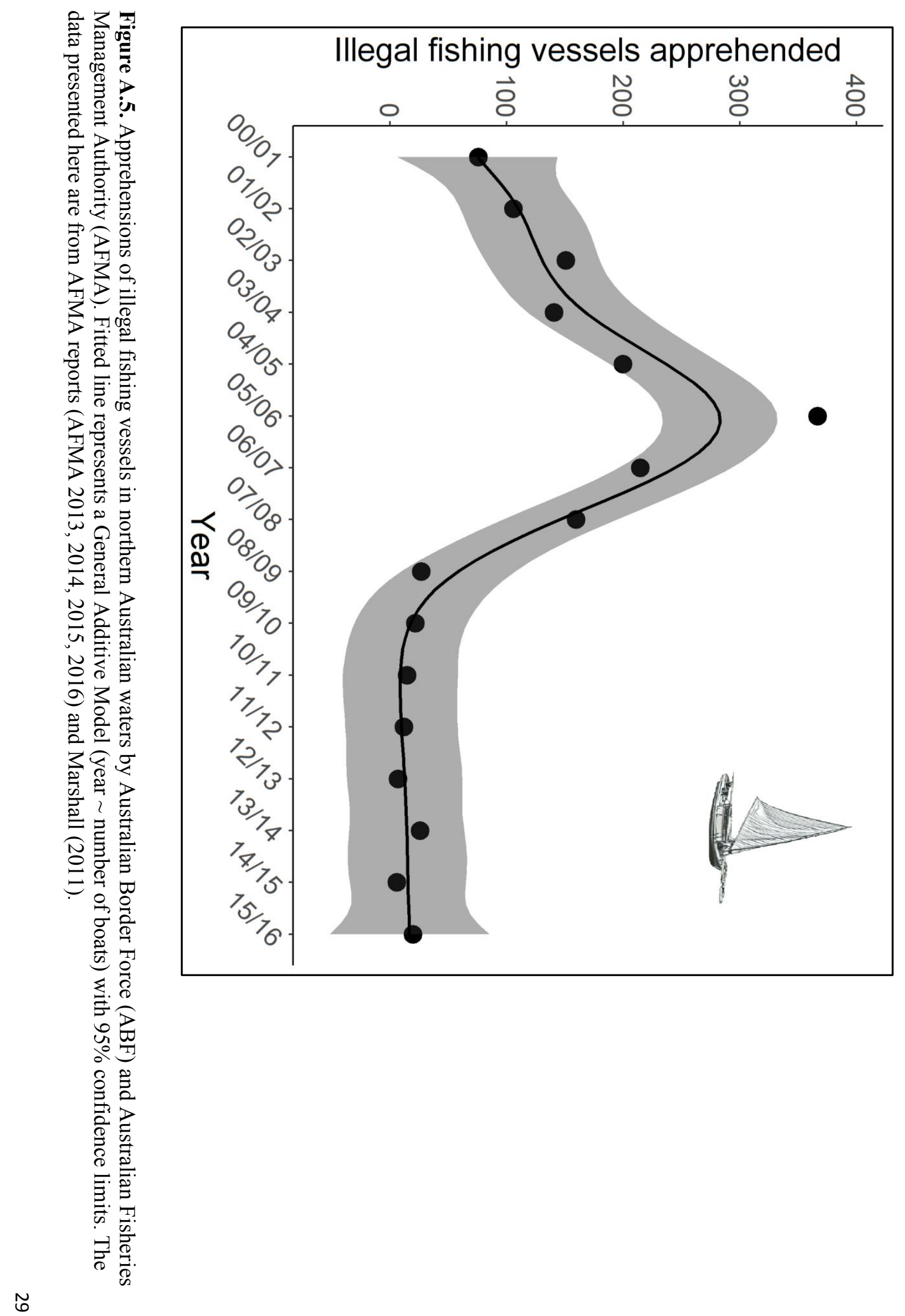




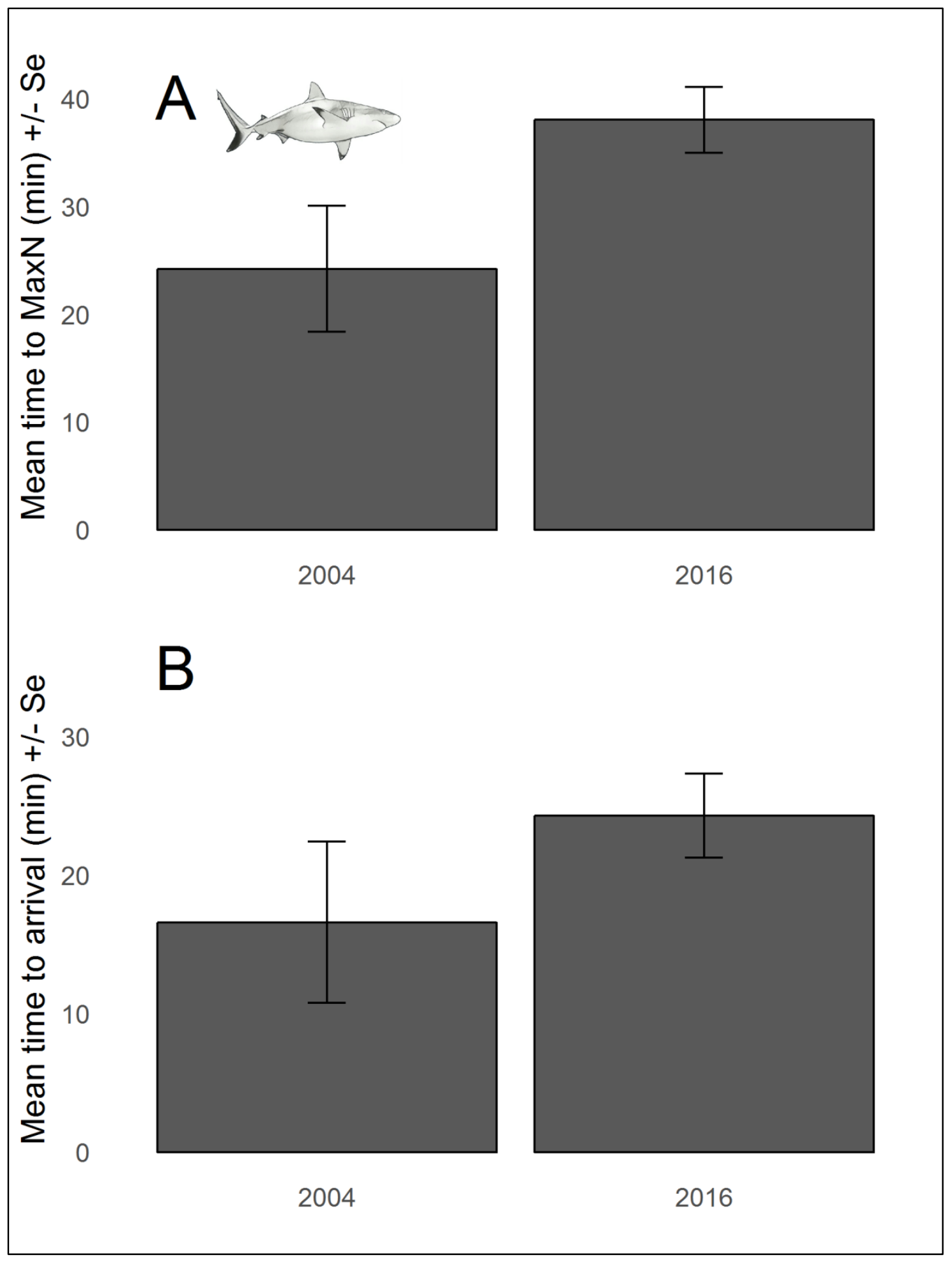

Figure A.6. A) Mean time to arrival ( \pm Se) of first $C$. amblyrhynchos seen on BRUVS B) Mean time to MaxN $( \pm$ Se) on BRUVS. Mean time to MaxN was quicker in $2004(24.2 \pm 5.8$ $\mathrm{SE})$ compared to $2016(38.0 \pm 3.0 \mathrm{SE})$, although this was a non-significant relationship $(\mathrm{t}=$ $2.10, \mathrm{df}=9.62, \mathrm{p}$-value $=0.06)$. Similarly, the mean time to arrival in $2004(16.6 \mathrm{~min} \pm 3.8$ $\mathrm{Se})$ was faster than in $2016(24.3 \pm 3.0 \mathrm{Se})$, although this was also a non-significant relationship $(\mathrm{t}=-1.58, \mathrm{df}=14.47, \mathrm{p}$-value $=0.13)$. 


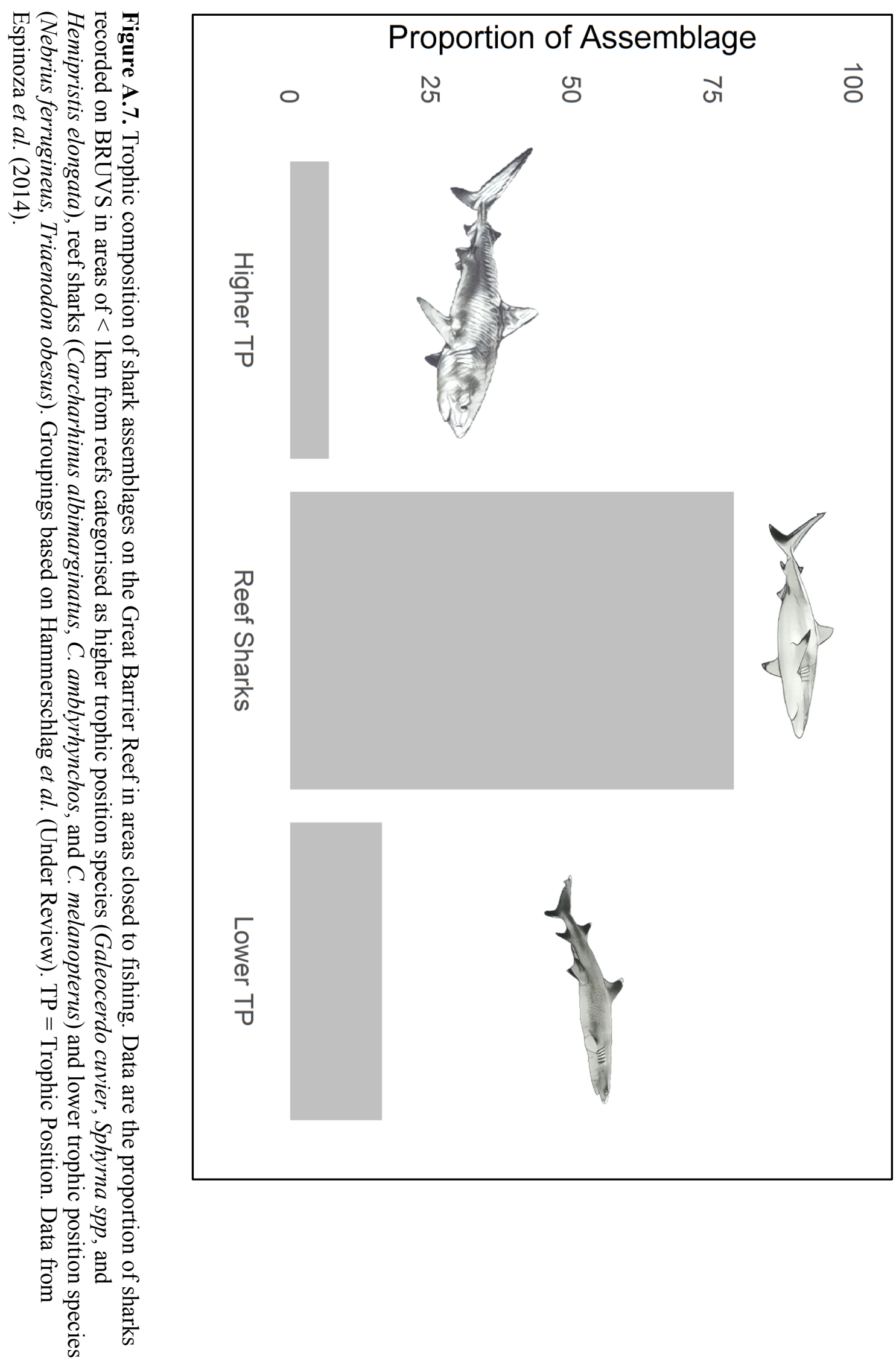

